\title{
Determinants of audit fees and the management of corporate disclosures
}

\section{- 1 1 | |

\author{
10110
}

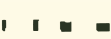

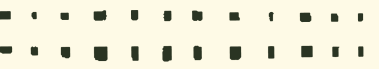





\title{
Determinants of audit fees and the management of corporate disclosures
}

\author{
Linus Axén
}

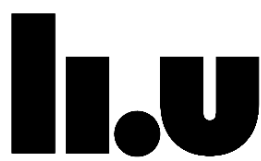

LINKÖPING UNIVERSITY

Linköping Studies in Arts and Sciences No. 779

Faculty of Arts and Sciences

Linköping 2020 
Linköping Studies in Arts and Sciences • No. 779

At the Faculty of Arts and Sciences at Linköping University, research and doctoral studies are carried out within broad problem areas. Research is organized in interdisciplinary research environments and doctoral studies mainly in graduate schools. Jointly, they publish the series Linköping Studies in Arts and Sciences. This thesis comes from the division of Business Administration at the Department of Management and Engineering.

Distributed by:

Department of Management and Engineering

Linköping University

SE-581 83 Linköping

Linus Axén

Determinants of audit fees and the management of corporate disclosures

Book cover: Original art by Giorgio Morara / Shutterstock.com

Edition 1:1

ISBN 978-91-7929-922-4

ISSN 0282-9800

(C) Linus Axén

Department of Management and Engineering 2020

Printed by: LiU-Tryck, Linköping 2020 


\begin{abstract}
Ever since Simunic (1980), a great deal of research has examined the pricing of auditing services. The absence of proprietary audit cost data forces most researchers to use audit fee models linking theoretical concepts to observable data. In order to make audit pricing more transparent, there is a need to examine the determinants of audit fees with regard to, for example, different organizational forms, institutional settings, and governance mechanisms. Regarding corporate disclosures, most prior research has investigated various determinants, although little field-based research has focused on the actual disclosure process. By focusing on disclosure practices, it is possible to explore the role of essential actors involved in the preparation of annual reports. The overall aim of this thesis is twofold: first, to explore theoretically salient influences on audit fees by analyzing the effects of client business risk, municipal ownership, and the content of internal audit disclosures, and second, to improve our understanding of how companies manage their corporate disclosures.

This thesis consists of a compilation of four papers and a comprehensive summary. The specific aim of each paper and current knowledge of the phenomenon under study have formed the basis for the methodological choices (interviews, content analysis, and regression analysis). The empirical material consists mainly of publicly available data from annual reports and of interviews with managers of listed companies, audit firms, and communication agencies. Given the twofolded aim of this thesis, evidence is provided that: (i) the determinants of audit fee cutting and relative audit fee pressure are considerably different, especially with regard to different client business risk factors; (ii) municipal companies are paying significantly lower audit fees than equivalent private companies; (iii) there is a considerable heterogeneity in internal auditing disclosures, and companies with more transparent firm-specific disclosures related to internal auditing pay lower audit fees than do those not providing such disclosures; and (iv) the management of corporate disclosure within the annual report is heavily influenced by the knowledge, skills, and personal characteristics of the project manager.
\end{abstract}

Keywords: audit fees, audit fee pressure, annual report, business risk, disclosures, hybrid organizations, internal auditing, project manager 



\section{Sammanfattning}

Ända sedan Simunic (1980) har ett stort antal studier undersökt prissättningen av revisionstjänster. Avsaknaden av företagsintern data över de faktiska revisionskostnaderna har tvingat majoriteten av alla forskare att använda revisionskostnadsmodeller, vilka länkar teoretiska koncept med observerbar data. För att göra prissättningen av revision mer transparant finns det ett behov av att ytterligare undersöka revisionskostnadernas bakomliggande faktorer med hänsyn till exempelvis olika organisationsformer, institutionella miljöer och styrningsmekanismer. Gällande informationsgivning från företag, har en stor andel av tidigare forskning undersökt olika bakomliggande faktorer, dock existerar det fåtalet fältstudier med fokus på den faktiska processen som ligger till grund för offentliggörande av information. Genom att fokusera på informationsgivning i praktiken är det möjligt att utforska rollen av väsentliga aktörer som är inblandade i framtagandet av årsredovisningar. Det övergripande syftet med denna avhandling är tudelat, först att utforska teoretiskt betydande influenser på bolags revisionskostnader genom att analysera effekterna av klienters affärsrisk, kommunalt ägande och innehållet i upplysningar kring internrevision, och för det andra, att förbättra vår förståelse för hur företag hanterar sitt informationsgivande.

Den här avhandlingen består av fyra artiklar och en sammanfattande kappa. Varje enskilt syfte i respektive artikel och det nuvarande evidensläget gällande studiefenomenet har legat till grund för de metodologiska övervägandena (intervjuer, innehållsanalys, och regressionsanalys). Det empiriska materialet består i huvudsak av publikt tillgänglig data från årsredovisningar och intervjuer med anställda på noterade bolag, revisionsbyråer, och kommunikationsbyråer. Med hänsyn till studiens tudelade syfte, påvisas följande resultat: (i) de bakomliggande faktorerna som förklarar en sänkning av revisionskostnaderna och en relativ press av revisionskostnaderna är betydligt olika, speciellt med hänsyn till olika faktorer relaterade till företags affärsrisk; (ii) kommunalägda fastighetsbolag har lägre revisionskostnader jämfört med likvärdiga privata bolag; (iii) det är en betydande heterogenitet gällande upplysningar kring internrevision och företag med mer transparanta företags-specifika upplysningar betalar lägre revisionskostnader jämfört med bolag utan dessa upplysningar; och (iv) styrningen av företags informationsutgivande $\mathrm{i}$ årsredovisningen är starkt influerad av projektledarens kunskap, kompetens och personliga karaktärsdrag.

Nyckelord: revisionskostnader, press av revisionskostnader, årsredovisning, affärsrisk, upplysningar, hybrida organisationer, internrevision, projektledare 



\section{Acknowledgements}

“Utan tvivel är man inte klok.” - Tage Danielsson, 1974

I have been dedicated to writing this thesis for many years, it has been a challenging journey with various obstacles and many late nights in front of my computer. By writing acknowledgments I am adding the final piece to the puzzle, a new dawn, a new day, a new life is finally waiting. This thesis would not have been possible without the help from a number of people, thanks everyone for your guidance, support, and encouragement.

First of all, I want to express my gratitude to the supervisors of my thesis. To Torbjörn Tagesson, without your persuasion skills and your faith in me I would not have made this journey. As my main supervisor you have always been giving me valuable feedback and your cheerful and positive attitude has served as a great source of inspiration. To Pernilla Broberg, my secondary supervisory, thank you for your emotional and professional support. I truly admire your selflessness and ability to be an empathetic listener, it has been an honor to have you as my supervisor. To both of you, I hope our collaboration will continue in the future, new challenges are waiting ahead of us.

Tobias Svanström, thank you for an excellent readthrough of my thesis and for giving me constructive comments at my final seminar. Your feedback helped me to further improve the quality of this thesis. To Karl Wennberg, I am very grateful for your insightful comments that you gave me during the final phase of this process. I am also glad that I had the opportunity to participate in your doctoral course, learning the application of different statistical techniques used in social science.

Johanna, I am very thankful for the fact that you joined me as a PhD student and that I have had the possibly to share a large part of my studies with you. You have always helped out with research, teaching and organizing in general. Thanks for all the exciting and stimulating discussions. To Rickard, what if this is as good as it gets? As my own private therapist, you have given me an unprecedent freedom of expression. Your encouragement has inspired me to complete this thesis, I am pleased to have you as a colleague and a very good friend. As we both know, if you hang in there long enough, good things can happen in this world. 
I would also like to thank all my colleagues at the division of Business Administration for creating a positive working environment, where I always have felt comfortable with being myself. Special thanks to all of my fellow PhD students for your help and inspiration. Birgitta, Aliaksei, Hugo, Alexander, David, Elisabeth, Svjetlana, and Christopher, I am thankful for having you all in my life. To Josefine, I am glad that we started our PhDs at the same time and that you kept me company day in and day out at work this summer. Thanks to all my friends for supporting me during this process, I am looking forward to being able to see you a bit more frequently soon. To all the interviewees, thanks for being so generous with your time and experience.

Warm thanks to my parents Rose-Marie and Mikael for making me the person that I am and thank you for all the support you have given me throughout the years. Frida, my beloved sister, you were there for me when I needed you the most. Thank you for taking such a great care of Elsa and being a really good aunt.

Finally, and most importantly, creating this thesis would not have been possible without you Sofie. To you I am forever grateful and I dedicate this thesis to you.

Elsa, my lovely daughter, you are my everything.

Linköping, December 2019

Linus Axén 


\section{Appended papers}

Paper I Axén, L. (2019). Determinants of fee cutting and relative fee pressure: A client business risk perspective. Working paper.

Paper II Axén, L., Tagesson, T., Shcherbinin, D., Custovic, A., \& Ojdanic, A. (2019). Does municipal ownership affect audit fees. Journal of Management and Governance, 23(3), 693-713.

Paper III Axén, L. (2018). Exploring the association between the content of internal audit disclosures and external audit fees: Evidence from Sweden. International Journal of Auditing, 22(2), 285-297.

Paper IV Axén, L., \& Broberg, P. (2019). The creation and control of annual report disclosures: Exploring the role and tasks of the project manager. Working paper.

The published articles are reprinted with permission from Springer Nature and Wiley. 



\section{Table of Contents}

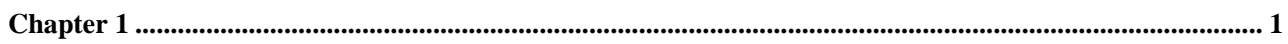

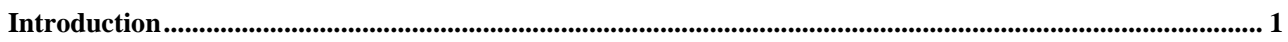

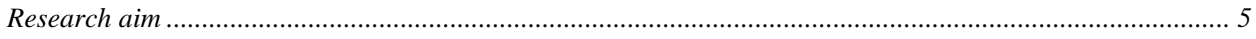

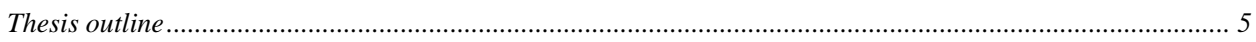

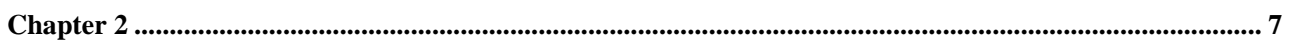

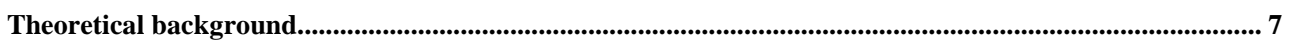

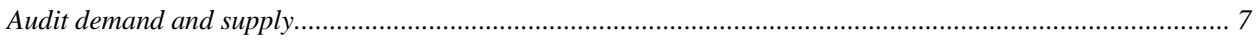

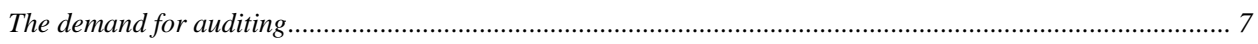

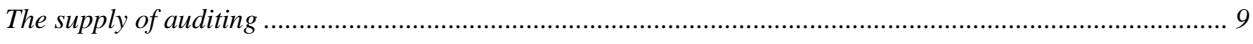

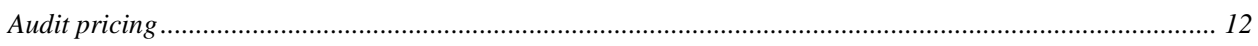

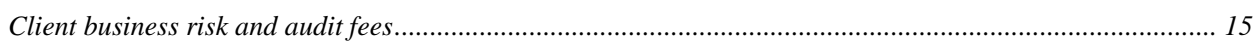

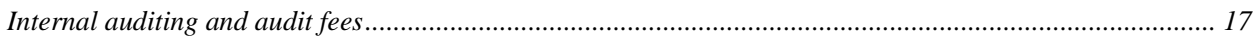

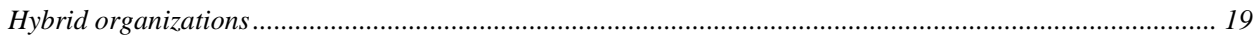

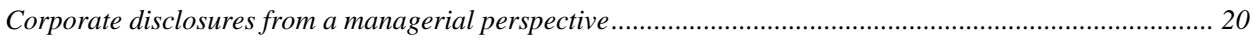

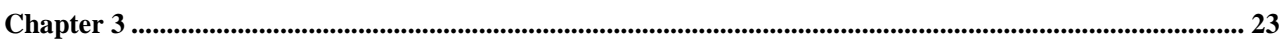

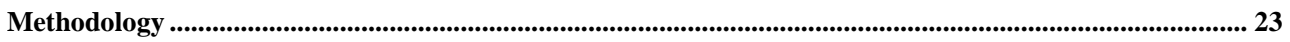

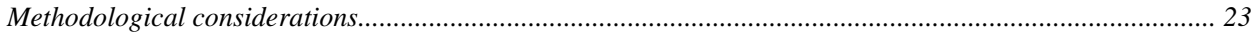

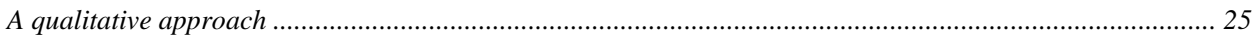

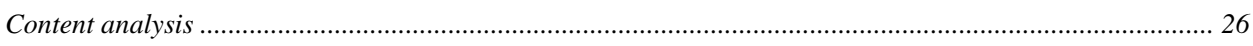

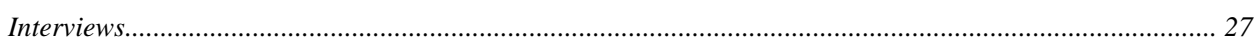

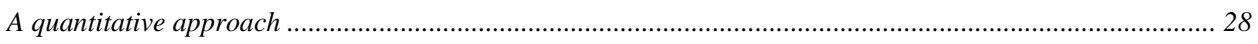

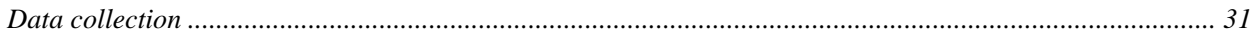

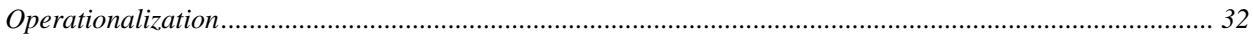

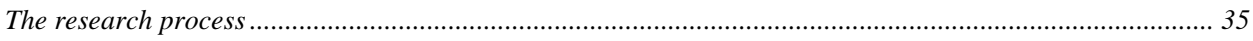

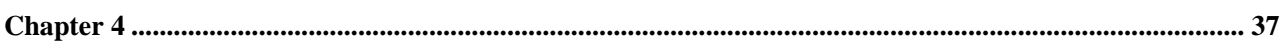

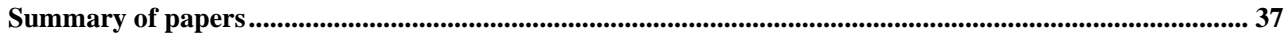

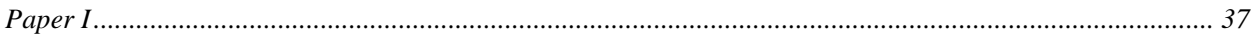

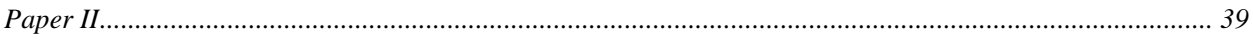

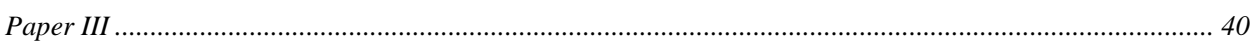

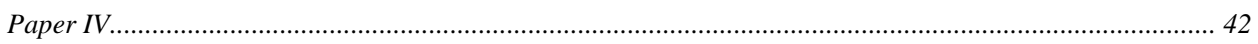

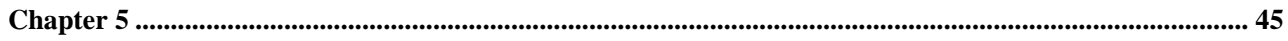

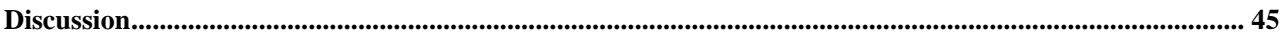

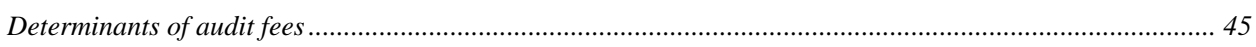




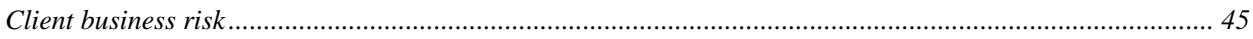

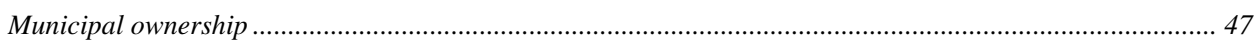

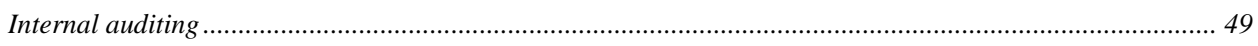

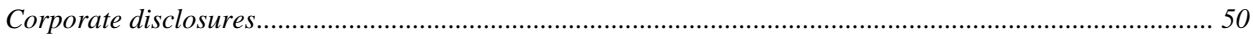

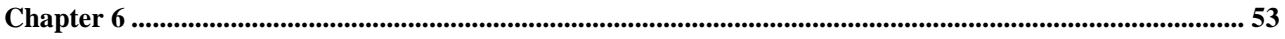

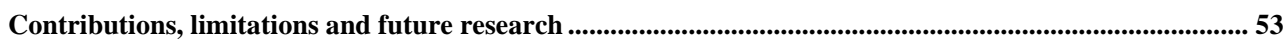

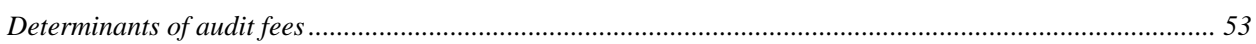

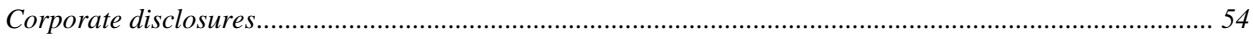

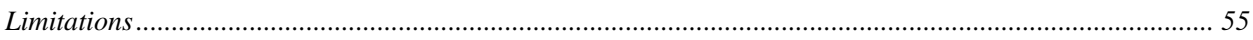

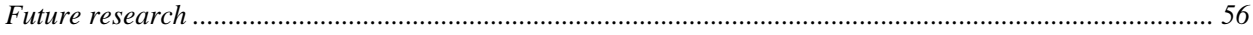

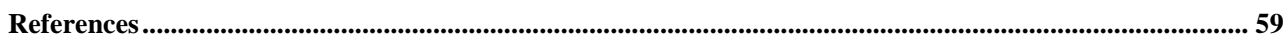

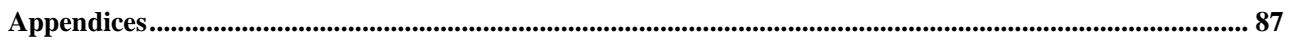

\section{Figures}

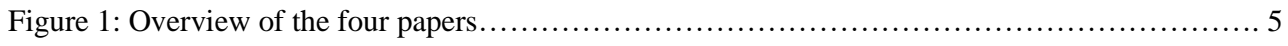

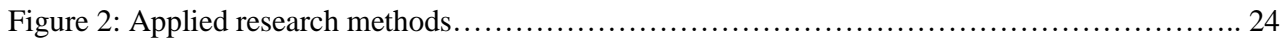

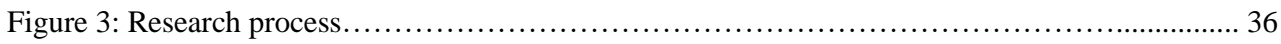






\section{Chapter 1}

\section{Introduction}

The market for audit services has been a topic of great interest, both for regulators and researchers, ever since the early 1970s (Causholli, De Martins, Hay, \& Knechel, 2011; Oxera, 2006; United States Senate, 1977; Willekens, Dekeyser, \& Simac, 2019). Concern regarding the competitiveness of the U.S. audit market was an initial stimulus for academic research related to audit pricing and audit production (Simunic, 2014). In order to investigate the existence of monopolistic pricing, Simunic (1980) developed an audit fee model that decomposed audit fees into two essential components, attributed to audit effort and the expected loss from litigation. Absence of proprietary audit cost data forced Simunic to relate the audit fees to different client attributes, essentially to client size, client complexity, and client risk. In addition to its initial use for investigating the competitiveness of the audit market (Eshleman \& Lawson, 2017; Francis, Michas, \& Seavey, 2013; Pearson $\&$ Trompeter, 1994), the seminal audit fee model has been used to explore the effects of, for example, industry specialization (Carson, 2009; Numan \& Willekens, 2012; Zerni, 2012), auditor quality (Craswell, Francis, \& Taylor, 1995; Gist, 1992; Ireland \& Lennox, 2002), and the joint provision of audit and non-audit services (Alexeyeva \& Svanström, 2015; Davis, Ricchiute, \& Trompeter, 1993; Ezzamel, Gwilliam, \& Holland, 1996). Furthermore, the seminal audit fee model has even been subject to several modifications, giving rise to a large number of new variables related to different supply and demand attributes (Hay, Knechel, \& Wong, 2006). However, despite several modifications, the core determinants of the audit fee model are robust and overall client size is the most important determinant of audit fees (Hay, 2013). Altogether, the audit pricing literature has received extensive attention in recent years and the great interest in modelling audit fees can partly 
be explained by the fact "that it makes audit pricing more transparent, which benefits the buyers of audit services and perhaps also the sellers" (Niemi, 2003, p. 3). Furthermore, the limited number of studies on audit production (mainly due to lack of proprietary data), makes it very important to enhance our understanding of audit fees, in order to add another piece to the puzzle of audit pricing (Causholli et al., 2011).

Although, prior research has examined audit fees within different organizational forms, i.e., listed companies (Craswell \& Francis, 1999; Firth, 1997; Holm \& Thinggaard, 2014), privately held companies (Chaney, Jeter, \& Shivakumar, 2004; Hope \& Langli, 2010; Sundgren \& Svanström, 2013), and municipalities (Collin, Haraldsson, Tagesson, \& Blank, 2017; Johnsen, Meklin, Oulasvirta, \& Vakkuri, 2004), our understanding of audit pricing within hybrid organizations ${ }^{1}$ is very limited. Much of the audit fee literature is dominated by research on U.S. listed companies, and several different organizational forms and institutional settings prevalent in other countries remain unexplored (Cobbin, 2002; Hay, 2013). Regarding opportunities within archival research, a recent article by Simnett, Carson, and Vanstraelen (2016) stresses the importance of organizational and institutional pluralism, emphasizing that "there are a wider variety of international settings that provide the opportunity to explore the impact of the audit and differences in audit quality across a variety of organizational forms, including charities, municipal entities, and superannuation/pension funds"(p. 22). Regarding the exploration of different organizational forms, this thesis focuses on hybrid organizations, particularly on municipal corporations in the real estate industry. Municipal corporations have grown rapidly in recent decades and they play an important role in the Swedish economy, with an aggregated turnover of approximately 200 billion Swedish kronor (Bergh, Erlingsson, Gustafsson, \& Wittberg, 2019; Erlingsson, Fogelgren, Olsson, Thomasson, \& Öhrvall, 2015). Their mixture of private and public characteristics makes the governance of hybrid organizations highly complex, and the demands facing municipal corporations are often contradictory as a result of multidimensional goals from different stakeholder groups (Grossi, Reichard, Thomasson, \& Vakkuri, 2017; Kickert, 2001). From an audit perspective, it is possible to argue that municipal corporations will be charged with higher audit fees due to their political

\footnotetext{
${ }^{1}$ See Axén et al. (2019) for a more comprehensive understanding of the concept of hybrid organizations and the hybridity of municipal corporations.
} 
affiliations (raising demands for monitoring as a result of potential political conflicts and competition between political representatives and parties) and increased public visibility (Baber, 1983; Cohen \& Leventis, 2013; Redmayne, Bradbury, \& Cahan, 2010). Furthermore, additional audit effort may be required in order to avoid potential mistakes that could be detected by the lay auditor, who, in addition to the external auditor, also expresses an opinion about the adequacy of internal controls. However, in contrast to previous argumentation, reduced accountability within municipal corporations in combination with a financially strong owner supports a contradictory relationship (Billis, 2010; Collin \& Tagesson, 2010).

Returning to listed companies and the market for audit services, there have been serious questions raised as to whether the occurrence of audit fee pressure impairs audit quality (IESBA, 2016; PCAOB, 2010). In response to this concern, previous research has investigated the impact of downward audit fee pressure on audit quality, and overall a negative association is supported (Beardsley, Lassila, \& Omer, 2019; Christensen, Omer, Sharp, \& Shelley, 2014; Ettredge, Fuerherm, \& Li, 2014; Ettredge, Fuerherm, Guo, \& Li, 2017; Krishnan \& Zhang, 2014). Although previous studies have investigated the consequences of fee cutting and fee pressure, the actual determinants are largely unexplored (one exception is Ettredge \& Greenberg, 1990). Regarding the importance of client business risk attributes when pricing audit services, this thesis examines the determinants of fee cutting and relative fee pressure with special emphasis on the financial aspects of the company. According to ISA 315 and ISA 330, auditors need to obtain a sufficient understanding of the client and its business risk in order to properly plan the audit and assess the risks of material misstatement. Essentially, business risk is related to the client's ability to achieve its objectives and hence is ultimately associated with the client's survival (Bell, Marrs, Solomon, \& Thomas, 1997; Johnstone, 2000). Regarding the pricing of audit services, auditors are able to respond to increased business risk either by increasing audit effort (i.e., higher production cost) and/or by charging a risk premium in order to cover potential future losses (Bell, Landsman, \& Shackelford, 2001; Kim \& Fukukawa, 2013; Niemi, 2002). Irrespective of the method used, the auditor's primary concern is to minimize the risk of suffering "a loss or injury to his professional practice" (Brumfield, Elliot, \& Jacobson, 1983, p. 60). Furthermore, in accordance with ISA 315, the risk assessment 
process is even directed to obtain an understanding of the client's internal controls and its internal audit function (if the entity has one). The internal audit function has a profound understanding of the organization and its internal controls, which makes it an important governance mechanism (Gramling, Maletta, Schneider, \& Church, 2004). However, despite the importance of the internal audit function, both internally (to managers and members of the board) and externally (to external auditors, regulators, rating agencies, and citizens), there are no regulatory disclosure requirements (Anderson \& Christ, 2014; Holt \& DeZoort, 2009). Lack of disclosure requirements related to the internal audit function creates broad discretion for managers to select information (on a voluntary basis) that they believe is relevant to external stakeholders (Meek, Roberts, \& Gray, 1995). This thesis aims to explore the content of internal auditing disclosures in annual reports and to explain its relationship to external audit fees.

In sum, the first three papers of this thesis explore different determinants of audit fees by analyzing the effects of client business risk, municipal ownership, and the content of internal audit disclosures. The fourth paper is more oriented towards the actual disclosure process and the management of corporate disclosures. Within existing audit literature, archival research (usually based on information included in the annual report) is the predominant research method used in international studies (Simnett et al., 2016); however, the authorship of corporate narratives and the understanding of disclosure practice is largely unknown (Beattie, 2014). Lack of transparency regarding corporate disclosures raises various questions, and there is a great need "to better understand the process of assembling corporate narrative documents at the level of CEOs/other corporate leaders/other managers" (Merkle-Davis \& Brennan, 2007, p. 62). In line with other field-based research (Gibbins, Richardson \& Waterhouse, 1990), this thesis aims to improve our understanding of how companies manage their corporate disclosures, for example, by identifying key actors involved in the disclosure process. 


\section{Research aim}

The overall aim of this thesis is twofold: first, to explore theoretically salient influences on audit fees by analyzing the effects of client business risk, municipal ownership and the content of internal audit disclosures, and second, to improve our understanding of how companies manage their corporate disclosures.
Determinants of audit fees
Disclosures

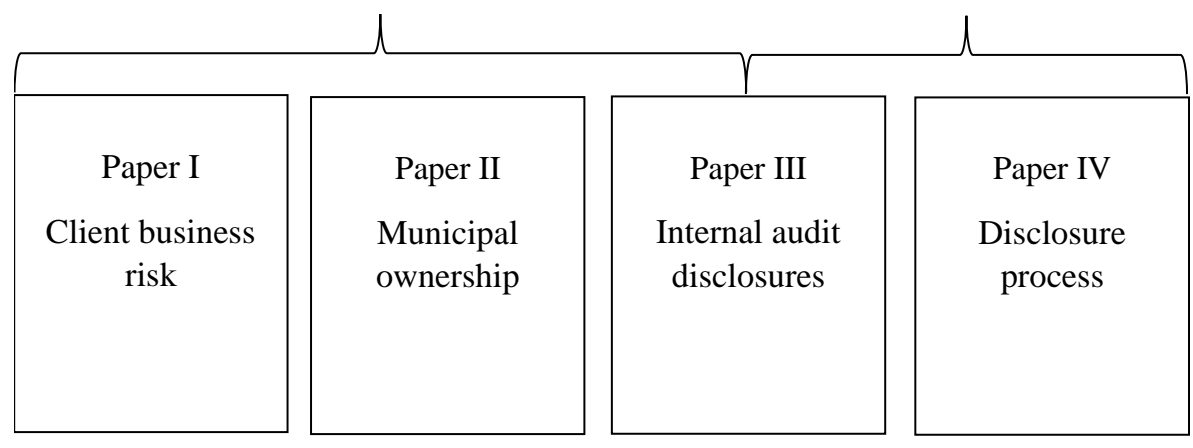

Figure 1: Overview of the four papers

\section{Thesis outline}

This thesis constitutes a compilation of four papers and a comprehensive summary. Chapter 2 presents the theoretical background, starting with theories on the demand and supply of audit services. Subsequently, the theoretical underpinnings of the seminal audit fee model are discussed, followed by a review of the most essential audit fee determinants. Finally, the unique characteristics of hybrid organizations are presented, followed by an overview of corporate disclosures. Chapter 3 describes the research design, data collection, and operationalization of the thesis. Chapter 4 summarizes the four appended papers that constitutes the basis of this thesis. Chapter 5 discusses the research findings according to the overall research aim. Chapter 6 concludes the thesis by identifying contributions and limitations, and gives some suggestions for future research. The second part of this thesis presents the complete versions of the four appended papers. 


\title{
Chapter 2
}

\section{Theoretical background}

\author{
Audit demand and supply \\ The demand for auditing \\ "...when the economic resources of one party are entrusted to another, human \\ nature is assumed to be weak, untrustworthy and in need of some kind of check."
} (Power, 1997, p. 16)

Essentially, the demand for auditing has evolved due to information asymmetries where "interested individuals or groups are unable for one or more reasons to obtain for themselves the information or reassurance they require" (Flint, 1988, pp. 14-15). Information asymmetry is a fundamental assumption within both agency and signaling theory, and the basic idea is that "different people know different things" (Stiglitz, 2002, p. 469). In the decision-making process, individuals evaluate the accessible information before selecting a suitable option. Information can be made available publicly or kept private in a subset of people within, for example, companies, households, or governments (Connelly, Certo, Ireland, \& Reutzel, 2011). By contractual arrangements, the principal appoints an agent to act on his or her behalf. A disadvantage of delegating duties and separating ownership from control is that the principal reduces his or her ability to observe if the agent is behaving in the best interest of the firm ( $\mathrm{Ng}, 1978)$. As managers may act in their own interest (i.e., moral hazard), shareholders have incentives to implement monitoring costs in order to limit the agent's ability to behave opportunistically (Jensen \& Meckling, 1976). The appointment of an independent auditor is used to mitigate agency costs, for example, by assessing the estimates made by management and by forming an opinion on the financial statements 
(Francis \& Wilson, 1988, Watts \& Zimmerman, 1986). In a compulsory setting, managers are able to reduce agency costs by voluntarily demanding a higher level of audit that exceeds minimum required standards (Hay, Knechel, \& Willekens, 2014).

As auditing is a social phenomenon, consideration needs to be given to social norms, cultural differences, and organizational structures (Flint, 1988). Auditing only exists because individuals have a need to obtain information about another party and they are unable to get that information on their own. As "audit is a social control mechanism for securing accountability" (Flint, 1988, p.17), it is of importance to consider the interaction between auditors, policymakers, and different interest groups. The surrounding society will always change, and auditors need to be responsive in order to meet the expectations of the society and act as a control mechanism (Power, 1997). In order to maintain public confidence and secure public trust, it is of importance that auditors make decisions that do not impair their independence (Beattie \& Fearnley, 2002; Sikka, Puxty, Willmott, \& Cooper, 1998). Even though auditors may have incentives to compromise independence in the short run (DeAngelo, 1981a), it is essential that they safeguard their reputation as auditing must be trusted to offers value to the users.

In situations with asymmetric information, signals could be used to carry information from well-informed to less-informed individuals (Spence, 1973; Spence, 2002). From a signaling theory perspective, managers have incentives to appoint an auditor, as this may enhance the credibility of the company's financial statements (Hay et al., 2014). According to financial theory, improved user confidence and reduced information asymmetry can increase the liquidity of the company's shares and consequently lower the cost of capital (Botosan, 1997; Diamond \& Verrecchia, 1991; Leuz \& Verrecchia, 2005). Based on DeAngelo (1981b) and following research (DeFond, 1992; Francis \& Wilson, 1988; Niskanen, Karjalainen, \& Niskanen, 2011), it is evident that there exists a heterogeneous demand for auditing, and companies with a higher level of agency conflict have incentives to use a larger (Big $\mathrm{N}$ ) audit firm offering higher audit quality. By exploring how changes in audit quality are associated with different levels of agency conflicts, DeFond (1992) provides evidence that companies have different demands for audit quality depending on changes in management ownership and leverage. Furthermore, managers of companies with higher accounting quality have incentives to hire an audit firm with higher audit quality in order to reduce 
investor uncertainty and to justify the use of, for example, unbiased performance measures (Becker, DeFond, Jiambalvo, \& Subramanyam, 1998; Datar, Feltham, \& Hughes, 1991; Wallace, 1980). In accordance with the insurance hypothesis (Wallace, 1980, 2004), clients may demand audit as a way of shifting financial responsibility to another party and thereby lowering the risk of financial losses. In particular, Big $\mathrm{N}$ audit firms are assumed to have "deep pockets", and previous findings of Lennox (1999) indicate that large audit firms are more prone to litigation despite providing higher audit quality. It is of importance to note that the demand for auditing is not only restricted to traditional principal-agent relationships; it is even possible to argue for an internal demand for auditing (Abdel-Khalik, 1993; Causholli et al., 2011; Knechel, Niemi, \& Sundgren, 2008). In exploring why private companies demand auditing, Abdel-Khalik (1993) provides evidence supporting his hypothesis that owners of private companies appoint an auditor as a response to increased organizational complexity and loss of control. Furthermore, Knechel et al. (2008) find evidence supporting the notion that the demand for auditing in smaller companies is primarily driven by internal benefits related to a company's organizational complexity and its operations. In sum, the demand for auditing is fundamentally driven by incentives to reduce information asymmetry problems, partly caused by separation of ownership and control. ${ }^{2}$ Different levels of agency conflicts create a heterogeneous demand for audit services and hence also audit quality. In order to build a more comprehensive picture of the audit market, the supply side of the market will be discussed in the next section.

\section{The supply of auditing}

"Firms in a global network have the dual advantage of being both global and local." (Carson, 2014, p. 25)

With regard to public companies, the audit market is highly concentrated and dominated by four global audit firm networks (Carson, 2014). In a recent study requested by the ECON committee, Willekens et al. (2019) present survey results indicating that more than $90 \%$ of all public interest entities (PIEs) in Sweden are audited by a Big 4 audit firm. In comparison

\footnotetext{
${ }^{2}$ Compared with public companies, the drivers of audit demand in private companies are often more heterogeneous and the role of auditing is less obvious (Knechel et al., 2008; Langli \& Svanström, 2014; Vanstraelen \& Schelleman, 2017).
} 
with other multinational companies, the Big 4 audit firms consist of networks of companies that are locally owned and managed (Meuwissen, 2014). With respect to the utilized structure, national audit firms have "to adapt to their different legal, cultural, and economic national environment" (Lenz \& James, 2007, p. 368), which creates a high need for flexibility. By being part of a global network, Big 4 audit firms are able to obtain economic gains by sharing resources (e.g., staff, knowledge, and technology) and creating industry specialist groups with a high level of expertise (Carson, 2009). The current structure of the supply side of the audit market creates barriers to entry, both for smaller competitors and foreign-owned audit firms (Carson, 2009; Gramling \& Stone, 2001; Lenz \& James, 2007). Regarding the oligopolistic nature of the audit market, several regulators have expressed concern that a low degree of competition may have a negative impact on audit quality (Francis, 2011; Oxera consulting 2006, 2007; United States Treasury, 2008). As a response to this issue, prior academic research (Eshleman \& Lawson, 2017; Francis et al., 2013; Kallapur, Sankaraguruswamy, \& Zang, 2010; Numan \& Willekens, 2012; Pearson \& Trompeter, 1994) has explored the effects of audit firm concentration. Using data on U.S. audit clients, Kallapur et al. (2010) and Eshleman and Lawson (2017) could not provide any evidence indicating that audit firm concentration would impair audit quality. Instead, their findings support the notion that there exists a positive association between audit quality (mainly proxied by abnormal accruals) and market concentration. Furthermore, Francis et al. (2013) complement prior research by conducting a cross-country analysis using data from 42 countries. Consistent with recent studies, Francis et al. (2013) provides evidence indicating that the overall Big 4 market share in a country is positively associated with the quality of audited earnings. With regard to the association between audit market concentration and audit fees, the empirical results of prior studies are mixed. Pearson and Trompeter (1994) and Numan and Willekens (2012) both find evidence that a higher audit market concentration negatively affects audit fees. Hence, it is of importance to note that Numan and Willekens (2012) use alternative measures of market competition inspired by spatial competition theory and the relative location of competing auditors. Conversely, by using U.S data spanning from 2001 to 2013, Eshleman and Lawson (2017) support the notion that a higher audit market concentration is associated with audit fee premiums when controlling for metropolitan statistical areas. 
Furthermore, regarding the structure of the audit market, audit firms are likely to differentiate themselves from their competitors through industry specialization (Casterella, Francis, Lewis, \& Walker, 2004; Craswell et al., 1995; Reichelt \& Wang, 2010). Given different levels of industry specialization, a separation can be made on the global level (Carson, 2009), national level (Balsam, Krishnan, \& Yang, 2003) office level (Numan \& Willekens, 2012; Reichelt \& Wang, 2010), and finally the auditor level (Goodwin \& Wu, 2014; Zerni, 2012). In essence, industry specialization (regardless of level) "is one way to manage the provision of high-quality audit services to clients" (Carson, 2009, p. 357). In response to client demand, the auditors will supply specialized services that enables them to improve their profit margins. From an economic perspective, industry specialization may generate cost savings as a result of economies of scale (Mayhew \& Wilkins, 2003). Substantial investments in both audit technology and human resources can be shared among all clients and improve operating efficiency (Fung, Gul, \& Krishnan, 2012). It is even possible to argue that industry specialists are able to charge a fee premium as a result of superior reputation, greater market share and the provision of higher audit quality (Mayhew \& Wilkins, 2003; Reichelt \& Wang, 2010).

Essentially, the individual characteristics of auditors are a key attribute influencing audit production, as the audit process is highly labor intensive (Langli \& Willekens, 2018; Stein, Simunic, \& O'Keefe, 1994). The idiosyncratic nature of audit engagements makes it of importance to carefully consider the composition of the audit engagement team (Flint, 1988; Knechel \& Shefchik, 2014). The resources needed to conduct an audit are client specific and "depend on the personnel available for an engagement, the abilities and expertise of the audit team, and the audit technology and methodology being used" (Knechel, Krishnan, Pevzner, Shefchik, \& Velury, 2013, p. 391). Accordingly, auditor knowledge and experience are important factors affecting the supply of audit quality; moreover, expertise is mainly acquired through a combination of instructions, training, and practice (Bédard \& Chi, 1993; Knechel et al., 2013). Regarding contextual factors, "auditing is heavily regulated, and both demand and supply/production of auditing is subject to various forms of regulation" (Langli \& Willekens, 2018, p. 160.). Regarding ex ante regulation, professional audit standards are of importance in order to uphold the quality of audit practice and make it possible to evaluate the audit process (Knechel, 2013; Carson, 2014). Regarding 
subsequent ex post controls, auditors have incentives to maintain compliance with auditing standards in order to avoid sanctions and potential litigations (Langli \& Willekens, 2018; Niemi, Knechel, Ojala, \& Collis, 2018). Accordingly, the litigation environment (i.e., legal system) is of importance when it comes to the actual behavior of auditors (Francis, 2011). In sum, the supply side of the audit market (for large public companies) is highly concentrated and dominated by four global audit firm networks. Despite the oligopolistic nature of the audit market (i.e., a low degree of competition), there is no evidence supporting a reduction in audit quality. The pricing and quality of audits supplied are found to be affected by the size of the audit firm, the degree of industry specialization, and the individual characteristics of the auditors. The pricing of audit services reflects complex interdependence among both demand- and supply-side factors, a further discussion of which will be presented in the next section.

\section{Audit pricing}

"To extract the effect of audit behavior on the market price, I developed an empirical model in which audit fees are a nonlinear function of client size and complexity, riskiness of client operations, and the identity of the auditor." (Simunic, 2014, p. 35)

In the late 1970s, several regulators in the U.S. expressed their concern regarding the competitiveness of the market for auditing services (Niemi, 2003; Simunic, 2014). As an initial response to raised concerns, Simunic (1980) was the first to investigate the existence of monopolistic pricing within the audit market. Absence of proprietary audit cost data forced Simunic to develop a positive model of the determinants of audit fees. Some basic assumptions underlying the audit fee model are: (I) both auditors and clients are risk neutral and seek to maximize their wealth; (II) audit quality is an experience good, meaning that the quality of an audit is unknown prior to purchase; and finally (III) the structure of the audit market for smaller and larger clients is different due to different competitive structures. Basically, the fundamental audit fee model developed by Simunic (1980) has the following structure:

$$
\mathrm{E}(\mathrm{C})=\mathrm{cq}+\mathrm{E}(\mathrm{d}) * \mathrm{E}(\theta),
$$


where $\mathrm{E}(\mathrm{C})$, is the auditor's expected total audit cost and cq corresponds to the total production costs, where $\mathrm{c}$ is the per-unit cost of resources used by the external audit (wage rate) and $q$ is the quantity of resources expended by the auditor in performing the audit (audit hours). Furthermore, $\mathrm{E}(\mathrm{d}) * \mathrm{E}(\theta)$ represents a liability cost component, where $\mathrm{E}(\mathrm{d})$ is the present value of potential ex post losses (e.g., loss of reputation, litigation costs), while $\mathrm{E}(\theta)$ denotes the ex post fraction of losses incurred directly by the auditor. Overall the audit fee model is based on two basic elements, portioned into production costs and expected future losses. Since there are limited opportunities to adjust audit fees after the fact to cover potential ex post losses, auditors are keen to cover (i.e., by charging higher audit fees) any losses incurred by the client (Simunic \& Stein, 1996). According to Akono and Stein (2014), the main purpose of the audit fee model "is to solve the problem of unobserved audit costs by building a structure linking unobserved constructs to observable data" (p. 279).

Turning back to the actual study by Simunic (1980), it was based on survey data from a random sample of U.S. companies, ending up with a final sample of 397 companies. By using his empirical audit fee model, Simunic tested his hypothesis as to whether there existed price differences between Big 8 and non-Big 8 audit firms. The results of his study provided no evidence supporting a fee premium for larger audit firms and hence no support for monopoly pricing by the Big 8 audit firms. Given the initial aim to investigate the issue of monopolistic pricing, the original audit fee model has been of great importance within the archival literature on audit fees. Since the seminal work by Simunic (1980), many subsequent studies have used and refined the original audit fee model in order to explore different determinants of audit fees (Hay et al., 2006; Hay, 2013). The audit fee model has even been subject to a number of technical modifications, such as the practice of using the natural logarithm of the continuous variables in response to the expected non-linearity between audit fees and client size (Cobbin, 2002). Further developed versions of the audit fee model have been tested in many different countries and institutional environments (Craswell et al.,1995; Gonthier-Besacier \& Schatt, 2007; Gul, 2006), ownership structures (Baber, 1983; Holm \& Thinggaard, 2014; Sundgren \& Svanström, 2013), and different time periods (Hay, Knechel, \& Li, 2006; Palmrose, 1986; Simunic \& Stein, 1996; Zain, Zaman, \& Zulkifflee, 2015). 
The determinants of audit fees are mainly related to different client attributes, more specifically, to client size, client complexity, and client risk (Hay, 2013). In the majority of previous studies, the most dominant determinant is exclusively the size of the client (Cobbin, 2002; Hay, 2013). Hence, considering public companies, a large proportion of the variance in the audit fee model (generally more than $70 \%$ ) is explained by total assets (Hay et al., 2006). An increased number of transactions will have an impact on the scope of an audit and consequently even on the total workload of the auditors (Firth, 1997). However, the association between client size and audit fees is unlikely to be linear, as the responsible audit firm will achieve economies of scale as client size increases (Gerrard, Houghton, \& Woodliff, 1994). From an agency theory perspective, it is possible to argue that larger companies will have a greater distance between the agent and principal, which creates increased monitoring costs (Nikkinen \& Sahlström, 2004). Regarding loss exposure, both reputational costs and litigation costs will be higher for larger clients, which creates incentives for the auditors to incorporate potential losses (i.e., via an audit fee premium) into the audit fees (Simunic \& Stein, 1996; Stice, 1991). Another important factor that influences audit fees is client complexity (Hay, 2013). Increased client complexity, for example, due to a more decentralized or diversified corporate structure, will lead to additional audit effort (i.e., more time-consuming work) and thus increased audit fees (Simunic, 1980; Chan, Ezzamel, \& Gwilliam, 1993). Furthermore, previous findings support the notion that client business risk is an important determinant of audit fees (Hay et al., 2006; Hay, 2013). The client's business risk can be decomposed into several different factors that all are related to the survival of the company (Bell, Doogar, \& Solomon, 2008; Erickson, Mayhew, \& Felix, 2000). Overall, previous research supports a positive relationship between client business risk and audit fees (Kim \& Fukukawa 2013; Niemi, 2002; Pratt \& Stice, 1994). A more detailed discussion of the association between client business risk and audit fees will be presented in the next section.

Considering auditor attributes, a large stream of research has examined auditor quality, industry specialization, and auditor tenure (DeFond \& Zhang, 2014; Reichelt \& Wang, 2010; Simon \& Francis, 1988). Big N audit firms are recognized to be of higher quality, and thus are able to earn audit fee premiums (Craswell et al., 1995; Gist, 1992; Ireland \& Lennox, 2002). Theoretically, Big $\mathrm{N}$ audit firms have stronger incentives to provide higher 
audit quality as they are subject to greater reputational risk (i.e., they audit larger clients and are subject to more public scrutiny) and increased litigation risk due to their "deep pockets" (Lennox, 1999; DeAngelo, 1981a). Regarding industry specialization, it can be used by audit firms as a strategy to differentiate their services and attract new clients (Mayhew \& Wilkins, 2003). By gaining a competitive advantage, industry specialists are able to increase their bargaining power and charge an audit fee premium (Reichelt \& Wang, 2010). On the other hand, it is even possible that industry specialization improves operating efficiency and generates cost savings (Fung, Gul, \& Krishnan, 2012; Mayhew \& Wilkins, 2003). Beyond prior declared determinants of audit fees, there are numerous other engagement (e.g., audit report lag, audit opinion, and non-audit services) and individual (e.g., audit partner gender, audit partner specialization, and number of signing auditors) attributes that evidently influence audit effort and audit fees (Knechel \& Payne, 2001; Ittonen \& Peni, 2012; Simunic, 1984). In sum, the current archival literature on audit fees can be traced back to Simunic (1980) and his seminal paper investigating the existence of monopolistic pricing within the audit market. Overall, the audit fee model decomposes the expected total audit cost into two essential components, portioned into production costs and expected future losses. The determinants of audit fees are primarily related to different client attributes (i.e., client size, client complexity, and client risk), where a large amount of the total variance is explained by client size. Client risk is hence of importance when determining the audit fees and its effects on audit pricing will be discussed in the next section.

\section{Client business risk and audit fees}

"Client business risk-the risk that an entity's business objectives will not be attained as a result of the external and internal factors, pressures, and forces brought to bear on the entity and, ultimately, the risk associated with the entity's survival and profitability.” (Bell et al., 1997, p.15)

According to ISA 315 and 330, the assessment of client business risk plays an important role in the planning of the audit and greatly influences the nature of subsequent audit procedures required to minimize the risk of an inappropriate audit opinion. The assessment of business risk is of importance as "most business risks have the potential to affect the financial statements either immediately or in the long run" (Eilifsen, Messier, Glover, \& 
Prawitt, 2014, p. 100). Fundamentally, business risk is the risk that the client will fail to meet its objectives, possibly eventually casting doubt on the client's ability to continue as a going concern (Bell et al., 1997; Johnstone, 2000). A wide range of factors could affect the client's business risk, for example, the nature of the entity and its organizational structure, industry conditions, and the regulatory environment (Eilifsen et al., 2014; Kim \& Fukukawa, 2013). In the audit fee model developed by Simunic (1980), auditors respond to a higher client business risk either by increasing audit effort or by charging a risk premium in order to cover potential ex post losses (i.e., loss of reputation and litigation costs).

Overall, prior research provides evidence supporting a positive association between client business risk and audit fees (Hay, 2013). In more detail, there are mainly two streams of research related to audit pricing and how auditors respond to higher client business risk. One stream of research focuses specifically on audit effort (e.g., audit hours and mix of labor inputs) and different engagement characteristics. (Bell et al., 2008; Bell et al., 2001; Houston, 1999; O’Keefe, Simunic, \& Stein, 1994). By using proprietary audit cost data from 422 U.S. audit engagements, Bell et al. (2001) analyze whether clients with increased business risk are charged with higher audit fees (captured as total number of audit hours and hourly charge). As expected by the authors, auditors respond to higher perceived business risk by increasing the total number of audit hours devoted to the engagement. However, this effect is not related to an increased hourly charge. Furthermore, O'Keefe et al. (1994) use experimental evidence to examine the relationship between different client characteristics and audit effort, measured as the quantity and mix of labor inputs. According to the results, client risk is associated with a significant change in both the quantity of labor input and the assignment of more experienced and specialized audit staff. A second stream of research focuses on the existence of a risk premium to cover possible future losses (Kim \& Fukukawa, 2013; Niemi, 2002; Simunic \& Stein, 1996). In a study conducted in the Finnish context, Niemi (2002) explores the existence of a risk premium for companies with a higher client business risk. The results indicate that clients pay higher audit fees (i.e., audit fee premium) when auditors perceive a higher than average client business risk. This result is partly confirmed by Kim and Fukukawa (2013) using data from Japanese Big-3 audit firms. However, most Japanese audit firms simultaneously increased the total production costs (i.e., increasing total audit hours or using more experienced staff) and charged a risk 
premium. It is important to note that prior empirical evidence on audit fee premiums is mixed, and previous studies by both Simunic and Stein (1996) and Bell et al. (2001) do not provide evidence supporting the existence of a risk premium.

\section{Internal auditing and audit fees}

"The IAF provides valuable inputs and guidance to the board, management, and the external auditors, who help facilitate effective governance processes."

(Anderson \& Christ, 2014, p. 231)

The internal audit function (IAF) is an important governance mechanism, and due to its unique position within the company, it can positively influence the oversight of organizational risks and internal control processes (Gramling et al., 2004). Even though there are differences between IAFs, the essential activities within the IAF normally include "risk assessments, control evaluations, financial and operational audits, fraud investigations, external audit support, and consulting engagements" (Anderson \& Christ, 2014, p. 231). The notion that internal controls and external auditing can be substituted one for another has been emphasized within the audit literature (Felix, Gramling, \& Maletta, 2001; Gros, Koch, \& Wallek, 2017; Prawitt, Sharp, \& Wood, 2011; Wallace, 1984). In a monopolistic setting, Simunic $(1980,1984)$ argues that clients will choose an optimum of internal and external control mechanisms, meaning that there will be a constant tradeoff between investing resources in internal controls and using more external auditing. By matching public data with survey responses from internal and external auditors, Felix et al. (2001) support a negative relationship between internal audit contribution and external audit fees. In more detail, according to their results, the total reduction in external audit fees is around $18 \%$ for clients who invest (on average) in internal auditing. A similar negative relationship between internal auditing (i.e., actual investments in the internal audit function) and audit fees is even shown by Wallace (1984). Some examples of internal audit activities that may contribute to reduced external audit fees are the provision of review assistance, improvement of internal controls, and the evaluation of risk management procedures. Finally, in a more recent study, Prawitt et al. (2011) examine whether the contribution of internal auditing affects the external audit fees by focusing on unexpected audit fees instead of the actual audit fees. According to their results, a higher IAF quality reduces the external 
audit fees, though only when internal auditors are utilized as direct assistants and not when audit work has been previously performed by the IAF without surveillance. Thus, the external auditor's reliance on the IAF is highly important when considering the association between internal auditing and external audit fees (Bame-Aldred, Brandon, Messier, Rittenberg, \& Stefaniak, 2013).

Contrary to the substitute perspective, expecting a negative association between internal auditing and external audit fees, there is evidence from a complementary perspective indicating that a greater use of internal auditing is associated with higher audit fees (Hay et al., 2006; Hay, Knechel, \& Ling, 2008; Sing, Woodliff, Sultana, \& Newby, 2014; Zain et al., 2015). Using Australian data, Goodwin-Stewart and Kent (2006) provide evidence that clients with a greater level of internal auditing have higher audit fees; one possible explanation, according to the authors, is that "firms committed to strong corporate governance are likely to engage in greater levels of internal auditing as well as being prepared to pay for a higher quality external audit" (Goodwin-Stewart \& Kent, 2006, p. 391). Furthermore, Zain et al. (2015) argue that greater use of the IAF (i.e., an increased number of internal reviews and audit reports) will likely even increase the workload of external auditors, as they may have to dedicate resources reviewing previous work done by the IAF. Regarding multiple stakeholders within public companies, it is even logical to argue that a wide range of different governance mechanisms (internal and external) will be used in order to, for example, protect the reputation of independent directors, secure the interests of shareholders, and uphold public confidence (Hay et al., 2008). Altogether, previous studies (Goodwin-Stewart \& Kent, 2006; Gros et al., 2017; Hay et al., 2008; Prawitt el al., 2011) have yielded mixed results, and two reasons may be the use of different empirical data (e.g., experimental, survey, and archival) and different empirical contexts. 


\title{
Hybrid organizations
}

\begin{abstract}
“...hybridity always symbolizes the process and product of a mixture of essentially contradictory and conflicting elements.” (Brandsen \& Karré, 2011, p. 828)
\end{abstract}

Hybrid organizations are commonly characterized by combining different (often conflicting) institutional logics and thereby operating in the intersection of the conventional categories of public, private, and non-profit operations (Battilana \& Dorado, 2010; Billis, 2010). As emphasized in the literature, there exists a mixture of different hybrid organizational forms ranging from state-owned enterprises (Alexius \& Grossi, 2018; Bruton, Peng, Ahlstrom, Stan, \& Xu, 2015), municipal corporations ${ }^{3}$ (Grossi \& Reichard, 2008; Knutsson \& Thomasson, 2017), and public-private partnerships (Sands, 2006; Shaoul, Strafford, \& Stapleton, 2012) to social enterprises (Doherty, Haugh, \& Lyon, 2014; Ebrahim, Battilana, \& Mair, 2014). Even though there is no overall definition of a hybrid organization, most scholars tend to agree that the demands facing hybrid organizations are often contradictory due to multiple logics (i.e., political and market orientations) and various principal stakeholders with different needs (Ebrahim et al., 2014; Kickert, 2001; Thomasson, 2009; Pache \& Santos, 2013). Hence, actors in the hybrid organizations need to handle the challenge of pursuing different or competing goals related to both social and financial factors (Grossi et al., 2017; Battilana, 2018).

Considering organizational hybridity within the public sector, it was essentially triggered by a wave of public-sector management reforms in the 1980s and 1990s (Hood, 1991; Hood, 1995). As a response to claims of inefficiency, absence of accountability, and corruption, various municipal services were corporatized and public-private hybrid organizations were created, inspired by the more "business-like manner" of the private sector (Almqvist, Grossi, Helden, \& Reichard, 2013; Christeansen \& Lægreid, 2011, Thomasson, 2017). The governance of municipally owned corporations is complex, and their hybridity creates challenges related to accountability concerns, multidimensional goals due to demands from

\footnotetext{
${ }^{3}$ See Erlingsson et al. (2014) and SALAR (2013) to get a more profound understanding about the governance and auditing of municipal corporation.
} 
different stakeholders, and lack of transparency (Erlingsson, Bergh, \& Sjölin, 2008; Lindqvist; 2013; Grossi et al., 2017). The reduced accountability within hybrid organizations (André, 2010; Billis, 2010) may partly be related to diverse demands from multiple stakeholders claiming accountability from both the democratic and market perspectives (Grossi \& Thomasson, 2015; Kankaanpää, Oulasvirta, \& Wacker, 2014). Furthermore, the public-private institutional nature of hybrid organizations even impairs overall transparency as a consequence of considering both public and civil law and weak mechanisms of accountability (Erlingsson et al., 2008; Erlingsson et al., 2015).

\section{Corporate disclosures from a managerial perspective}

“...it is management and not the 'firm' that makes disclosure decisions."

(Beyer, Cohen, Lys, \& Walther, 2010, p. 305)

A large amount of accounting research has investigated managers' voluntary disclosure choices and their financial reporting decisions (Beyer et al., 2010; Healy \& Palepu, 2001). Because of inconclusive and contradictory empirical evidence, "the incentives to voluntarily disclose information can be explained in terms of a variety of economic and managerial theories, each of which focuses on a different aspect of corporate behavior" (Beattie \& Smith, 2012, p. 472). In a review of literature on discretionary narrative disclosures, Merkl-Davies and Brennan (2007) make a distinction between two different schools of thought, which each explains disclosure choices from a managerial perspective. The first school of thought, i.e., the incremental information school, is largely based on economic theory and its assumptions regarding utility maximization and a semistrong/strong form of market efficiency (Merkl-Davies \& Brennan, 2011). From this perspective, discretionary narrative disclosures will be used to reduce information asymmetries (i.e., add value-relevant and useful incremental information) and in the end to improve investors' decision making. Managers have incentives to provide unbiased information to users in order to strengthen their reputation and increase their managerial compensation (Baginski, Hasell, \& Hillson, 2000).

The second school of thought, i.e., the impression management school, is influenced by social psychology and aims at understanding "how individuals present themselves to others 
in order to be perceived favourably"... (Hoogheimstra, 2000, p. 60). In the context of corporate reporting, impression management is used by managers to manipulate narrative information and distort users' perceptions of corporate performance (Godfrey, Mather, \& Ramsay, 2003; Leung, Parker, \& Courtis, 2015; Rutherford, 2003). Different impression management strategies have been identified within the literature, and two types of managerial behaviors are named concealment and attribution. Concealment can be achieved by obfuscating negative information, for example, by using different writing techniques and a textual complexity that reduces the ability of readers to interpret the intended message (Courtis, 2004; Rutherford, 2003). It can also be achieved by emphasizing good news and neglecting or reducing the reporting of information that is negative (Abrahamson \& Park, 1994; Rutherford, 2005). Attribution is a strategy that assumes that managers act in a selfserving manner. Positive outcomes will more likely be attributed to internal factors, such as personal abilities and negative outcomes to external factors that managers have little or no control over (Aerts, 2001, 2005; Libby \& Rennekamp, 2012).

Overall, agency theory and the concept of economic rationality have been prominent in previous studies, assuming that managers are self-interested utility maximizers who aim to increase their managerial compensation (Merkl-Davies \& Brennan, 2007). However, a broader systems-oriented perspective can be used to illustrate how decision making by managers is influenced by societal norms and rules (Diouf \& Boiral, 2017; Merkl-Davies, 2011; O'Dwyer, 2002). Given the risk that "societal bounds and norms may change over time, the organisation continuously has to demonstrate that its actions are legitimate and that it behaved as a good corporate citizen" (Hoogheima, 2000, p. 56). In order to maintain and restore organizational legitimacy, managers are able to influence the public perception of the company by voluntarily disclosing information that aligns undertaken activities (i.e., pretended activities) with societal norms (Ashforth \& Gibbs, 1990; Neu, Warsame, \& Pedwell, 1998). Compared with mandatory financial reporting, the scope of narrative disclosures extends beyond a traditional investor perspective and addresses a more diverse group of stakeholders with other demands (Boesson \& Kumar, 2007). Increased public and regulatory pressure to invest in corporate social responsibility activities and corporate governance (Spira \& Page, 2010; Trotman \& Trotman, 2015) forces management to consider both primary and secondary stakeholders (Thijssen, Bollen, \& Hassink, 2015). The 
provision of sensible and firm-specific information will help the company to maintain confidence and a good reputation among shareholders and other stakeholders (Armitage \& Marston, 2008). 


\section{Chapter 3}

\section{Methodology}

\section{Methodological considerations}

"Good research, regardless of method, aims to better understand reality"

(Power \& Gendron, 2015, p. 153)

The methodological choices made in this thesis they are guided by the specific aim of each paper and the current knowledge of the phenomenon being studied (Birnberg, Shields, \& Young, 1990). For the past several years, the idea of methodological pluralism has received wide attention within the accounting and auditing literature and is growing in popularity (Hoque, Covaleski, \& Gooneratne, 2013; Modell, 2010; Wouters \& Wilderom, 2008). In stressing the relevance of different methodological approaches, Power and Gendron (2015) encourage diverse research methods as "a thorough understanding of an object of study can never be achieved by examining it from a single perspective" (p. 148). In this thesis, two of the appended papers (II and III) have adopted a mixed methods approach in order to get a more complete and comprehensive understanding of the phenomenon under study (Creswell \& Plano Clark, 2007). Some advantages of mixed method research are: (i) the weaknesses of each individual method can be offset by combining the strengths of both qualitative and quantitative research; (ii) the use of mixed methods makes it possible to get access to different facets of the same phenomena; (iii) mixed methods can increase the validity of the research results; and (iv) mixed methods allow the researcher to expand the scope and focus of the study (Greene, Caracelli, \& Graham, 1989; Johnson \& Onwuegbuzie, 2004). It is of importance that the researcher should have extensive knowledge of the methods used in order to mix them appropriately and create a well-integrated research design (Johnson, Onwuegbuzie, \& Turner, 2007). There are many different mixed method 
designs that can basically be classified into two different types: simultaneous (data collection and analysis conducted at the same time) or sequential (data collection and analysis conducted in two different phases).

Given the aim and scope of paper II, a sequential explanatory design was used (Creswell, 2009), where the statistical analysis of quantitative data was followed by semi-structured interviews. The subsequent analysis of the interviews made it possible to explore the quantitative results in more detail and to put forward alternative explanations not provided by previous research (Ivankova, Creswell, \& Stick, 2006). For paper III, it was appropriate to use a sequential exploratory design where an initial qualitative phase with data collection and analysis was followed by a subsequent quantitative phase (Creswell, 2014). In more detail, a content analysis made it possible to generate categories that could be used as independent variables, which were tested in a subsequent statistical analysis. Regarding the other two papers appended to this thesis, paper I is based on a quantitative method, hypothesis testing, and paper IV is inductively driven and based on semi-structured interviews. The applied research methods and their connections to each paper are shown in Figure 2.

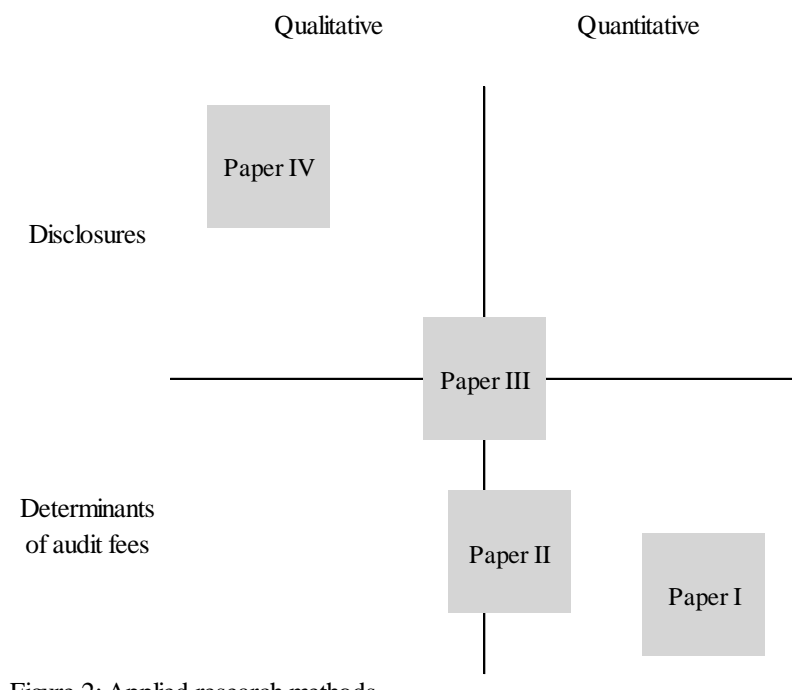

Figure 2: Applied research methods 


\section{A qualitative approach}

The explorative nature of this thesis justifies the use of a qualitative approach (Creswell, 2007). Qualitative research encompasses a wide range of approaches (Meriam, 2009; Patton, 2002) that overall "seek to describe, decode, translate, and otherwise come to terms with the meaning, not the frequency, of certain more or less naturally occurring phenomena in the social world" (Van Maanen, 1979, p. 520). A qualitative approach allows the researcher to get a grounded understanding of the research problem by discovering the underlying reasons, opinions, and motivations of individuals (Strauss \& Corbin, 1998). Furthermore, qualitative research has the potential to give unique insight into complex social processes and to question taken-for-granted assumptions (Rynes \& Gephart, 2004; Starks \& Trinidad, 2007).

The accounting and auditing literature it is largely dominated by quantitative research (Endenich \& Trapp, 2018; Simnett et al., 2016), though qualitative studies have grown in importance in the past two decades (Parker, 2003; Power \& Gendron, 2015). The overall growth of qualitative research involves a wide range of research approaches, for example, case studies, interviews, observations, and content analysis (Beattie, McInnes, \& Fearnley, 2004; Broberg, 2013; Cooper \& Morgan, 2008; Gendron, Bédard, \& Gosselin, 2004). Qualitative studies exploring the practice of accounting and auditing are of great importance in order to avoid a fabricated form of audit practice based on, for example, constructed experiments (Humphrey, 2008). As noticed by Roberts (2018), "accounting is not a science, but an ubiquitous practice very amenable to diverse social science investigations into its purposes, uses, and consequences" (p.73). Given these diverse social processes and actual decision making, qualitative research has the ability to "rehumanize research and theory by highlighting the human interactions and meanings that underlie phenomena and relationships among variables" (Rynes \& Gephart, 2004, p. 455). A qualitative research approach has been adopted, to varying degrees, in three of the appended papers. In paper II, semi-structured interviews (in addition to the statistical analysis) were used in order to further interpret the statistical results and to explore alternative explanations. In paper III, a content analysis made it possible to investigate variation in disclosure practice and to generate inductive categories. Finally, paper IV is based solely on semi-structured interviews with corporate managers and partners of communication companies. 


\section{Content analysis}

Content analysis is a research method that makes it possible to analyze qualitative data derived from, for example, interviews, observations, photographs, books, and articles (Hsieh \& Shannon, 2005). From a historical perspective, content analysis has mainly been considered a quantitative research method with a focus on the manifest content of communication (Graneheim \& Lundman, 2004). By including a qualitative perspective (Krippendorff, 2013; Neuendorf, 2002; Weber, 1990), contemporary content analysis has developed into a method that even considers the underlying meaning of the latent content. Within accounting research, content analysis has mainly been used in order to analyze the nature of corporate disclosures in annual reports and the use of impression management (Beck, Campbell, \& Shrives, 2010; Steenkamp \& Northcott, 2007). As the aim of paper III is to explore the content of internal audit disclosures in annual reports, a content analysis was used as a research method in order to classify the internal audit disclosures into categories and investigate variation in disclosure practice. Due to a lack of previous research into the practice of internal auditing disclosures, it was necessary to use a conventional approach based on an inductive categorization process, with a primary focus on understanding the empirical data (Hsieh \& Shannon, 2005; Mayring, 2000). Similar to previous studies by (Beck et al., 2010; Vourvachis \& Woodward, 2015), the annual reports of listed companies were "distinguished for selective inclusion" in the analysis and hence used as sampling units (Krippendorff, 2018). In a subsequent stage, systematic reviews of the annual reports were performed in order to identify existing internal auditing disclosures and to locate applicable context units. A context unit "is the body of material surrounding the coding unit" McMillian (2000, p. 82.), which is the main unit of analysis (Bengtsson, 2016). The internal auditing disclosures were mainly clustered and restricted to specific parts of the annual report, which justified use of paragraphs as context units. In accordance with most of previous studies within accounting research (identified in a review by Jones $\&$ Shoemaker, 1994), themes were selected as coding units and used in the categorization process. The inductive coding process started with a careful reading and examination of all disclosures in order to gain an overall impression of the data (Thomas, 2006). Subsequently, a coding process started through an "open coding", where identified coding units were marked and named in order to label the original text and conceptualize the data (Elo \& Kyngäs, 2008). Initially, a large number of categories were generated; these were 
progressively reduced through continuous refinement, ending up with eight core categories (Creswell, 2012; Thomas, 2006). The trustworthiness of paper III was enhanced in several different ways: (i) use of publicly available data facilitates scrutiny by other researchers who have unrestricted access to the annual reports; (ii) a total selection of all listed companies on Nasdaq Stockholm minimizes the risk of sampling bias; (iii) the inclusion of key quotations (for each of the categories) makes the analysis more transparent; and finally, (iv) independent coding was conducted by another researcher in order to demonstrate the reliability of the research findings (Elo \& Kyngäs, 2008; Krippendorff, 2013; Shenton, 2004).

\section{Interviews}

In two of the appended papers (papers II and IV), interviews have been used as a data collection method. Interviews are a qualitative method that is highly efficient when the researcher is interested in gathering rich and detailed empirical data (Eisenhardt \& Graebner, 2007; Polkinghorne, 2005). Furthermore, interviews are desirable for obtaining information about the respondent's experience, emotions, and knowledge (Denscombe, 2010; Patton, 2002). Qualitative interviews even make it possible to expand our "understanding of actual human interactions, meanings, and processes that constitute reallife organizational settings" (Rynes \& Gephart, 2004, p. 455). Given the exploratory aim of this thesis, semi-structured interviews were carried out with a wide range of participants belonging to listed companies, communication companies, and audit firms. Semi-structured interviews are commonly utilized within qualitative studies, largely due to their inherent flexibility and ability to reveal "important and often hidden facets of human and organizational behavior" (Qu \& Dumay, 2011, p. 246). Interview guides with open-ended questions were designed and sent to the participants in advance in order to invite the participants to review the questions and to increase their overall comfort in the interviews. Open-ended questions are beneficial as they allow the participants to organize their answers and to provide a wealth of details (Aberbach \& Rockman, 2002). For paper II, semistructured interviews were conducted (in addition to the statistical analysis) in order to improve the validity of the results and to enhance our understanding of audit pricing within municipal corporations (Patton, 2002). A sequential explanatory strategy made it possible to use qualitative results in order to further interpret the quantitative findings of the statistical analysis (Creswell, 2009). The sampling process was based on Alvesson's (2011) 
principles of representativeness and quality; accordingly, five partners from different audit firms were selected based on their previous experience and expert knowledge. In order to match the characteristics of the sample used in the statistical analysis, it was essential to focus on partners from Big 4 audit firms. Structural coding emphasizing the actual meaning was utilized to analyze the empirical material (Neunendorf, 2002; Saldaña, 2009). Overall, it was essential to focus on data that were related to the actual topic of inquiry.

For Paper IV, interviews were used as the primary source of empirical data. Semi-structured interviews were conducted with nine highly experienced directors (i.e., IR managers, corporate communication, managers and one CEO) of large-cap companies listed on Nasdaq Stockholm and with three partners and owners of leading Swedish communication agencies. In accordance with paper II, the respondents were selected with regard to the principles of representativeness and quality (Alvesson, 2011), so it was essential to select highly experienced respondents from a broad range of different industries. Due to the heavy workloads of all of the respondents and a great need for flexibility, nine out of 12 interviews were conducted by telephone. In line with previous research (Holt, 2010; Sturges \& Hanrahan, 2004) and according to my own experiences, the results of the telephone interviews did not differ significantly from those of more traditional face-to-face interviews. Several measures were taken to ensure the trustworthiness of the empirical data (Lincoln \& Guba, 1985). As mentioned previously, a copy of the interview guide was sent to the participants in advance in order to invite the participants to review the questions and so they could decide if they wanted to withdraw from participation based on the question content. Furthermore, to enable a more rigorous data analysis, each of the interviews (except one) was recorded and transcribed in verbatim. Each respondent was given the right to decline to be recorded, and all of the respondents were promised confidentiality. The interview material was subject to a thematic analysis, highly influenced by the approach of Braun and Clarke (2006).

\section{A quantitative approach}

Quantitative research heavily relies on numerical data and encompasses a wide range of different mathematical and statistical models that are used to explain the phenomena of interest (Gall, Gall, \& Borg, 1999; Goertz \& Mahoney, 2012; Olusegun, 2002). According to Creswell (1994), quantitative research can be defined as "an inquiry into a social or 
human problem based on testing a theory composed of variables, measured with numbers, and analyzed with statistical procedures, in order to determine whether the predictive generalizations of the theory hold true" (p. 2). Regarding the epistemological, theoretical, and methodological standpoints, quantitative research assumes that reality is objective, so it is of importance that the researchers distance themselves from the phenomena being studied (Yilmaz, 2013). Furthermore, the primary aim is to develop explanatory relationships, between and among variables, that can be generalized to a larger population (Maxwell, 1992; Winter, 2000). Quantitative research is essentially deductive, meaning that theoretical hypotheses are constructed before any applicable research is done (Creswell, 2014). A wide range of different quantitative methods exists, where an essential distinction can be made between experimental and a survey/correlation designs (Bryman \& Cramer, 2005; Singh, 2006).

In this thesis (papers I to III), various regression models have been used in order to analyze the empirical data. Basically, "the key idea behind regression analysis is the statistical dependence of one variable, the dependent variable, on one or more other variables, the explanatory variables" (Gujarati, 2004, p. 31). Multiple regression analysis is a dependence technique commonly utilized in business research to explore different types of dependence relationships (Hair, Black, Babin, \& Andersson, 2014). The multiple linear regression equation is as follows:

$$
y_{i}=a+\beta_{1} x_{i 1}+\cdots+\beta_{K} x_{i K}+\varepsilon_{i},
$$

where $y_{i}$ is termed as the dependent variable and $a$ is the intercept. The subscripts from $x_{i 1}$ to $x_{i K}$ represents the various independent variables, $\beta_{1}$ to $\beta_{k}$ are the unknown regression coefficients, and $\varepsilon_{i}$ is the error term (Verbeek, 2012). Technically, linear regression analysis is generally based on the ordinary least square (OLS) estimation method, where the bestfitting line for the observed data is calculated by minimizing the sum of the squared differences between observed and predicted values (Gujarati, 2004). OLS regression is a commonly used approach when analyzing audit fees (Cobbin, 2002). However, due to a non-linear relationship between audit fees and client size (partly explained by cost advantages that auditors can achieve through economies of scale), it has been generally accepted to use the logs of audit fees and client size (Hay et al., 2006). In paper II, an OLS 
regression was used to investigate the relationship between municipal ownership and audit fees. The independent variable was operationalized as a dummy variable, given the value of 1 if the company was municipally owned and 0 otherwise. The binary nature of the independent variable (dummy variable) was thus used to estimate differences between municipal corporations and private corporations within the real estate and housing industry. For paper III, a categorization of internal auditing disclosures was followed by statistical analysis (OLS regressions) investigating the relationship between internal auditing disclosures and audit fees. The independent variables were mainly based on the content analysis, with a primary aim to capture the total number of disclosures and the disclosure of firm-specific information.

The combination of cross-sectional and time series data is called panel data and is used in paper I (Gujarati, 2004). Over the last decade, panel data have started to grow in importance in the auditing literature (Hay, 2013), and it offers the potential to explore questions and capture complexity that cannot be addressed using cross-sectional data (Akono \& Stein, 2014). Panel data have several important advantages over cross-sectional data: (i) estimations based on panel data are often more precise than, for example, those based on cross-sectional and time series data since the explanatory variables consider two different dimensions, individual and time; (ii) it is possible to control for time-invariant unobserved heterogeneity; (iii) it is easier to handle endogeneity among explanatory variables; and (iv) it usually offers more sample variability and degrees of freedom (Hsiao, 2006; Verbeek, 2012; Wooldridge, 2002). Due to a non-continuous dependent variable, the main analysis in paper I is based on a logistic panel data regression, with both fixed effects and random effects models. In contrast to OLS regression, the logit model predicts the log-odds of an outcome occurring and is normally estimated by the maximum likelihood method (Verbeek, 2012, Wooldridge, 2002). The independent variables in paper I are all expected to capture different aspects of client business risk, essentially from a financial perspective. A strong correlation and a high value inflation value (VIF) value between two of the independent variables indicated potential problems with multicollinearity; as a result, two of the independent variables were included in separate regression models. 


\section{Data collection}

According to the aim of this thesis to extend our understanding of the determinants of audit fees, is was essential to get access to appropriate financial and non-financial data. An absence of proprietary audit cost data forced Simunic (1980) to develop an audit fee model and to use survey data from a random sample of U.S. companies. Contemporary audit fee disclosure requirements have reduced the need for survey data and have made it possible to use publicly available archival data. Hence, the different audit fee papers appended to this thesis (papers I-III) made use of archival data collected from annuals reports, different databases (i.e., Amadeus, Retriever Business, and Reuters 3000 Xtra), and a Swedish magazine called Aktiespararen. Empirical data were collected both at a certain point in time (cross-sectional) and at repeated times for the same object (longitudinal). In all of the appended papers, financial companies were excluded due to their unique regulatory and reporting requirements (Gonthier-Besacier, 2007).

The first and third papers are based on data pertaining to Swedish companies listed on Nasdaq Stockholm. In more detail, the empirical data in paper I cover 123 listed companies studied from 2006 to 2015. Hence, the total number of company-year observations in this paper is 1230 . It is important to note that all companies covered in paper I were listed on Nasdaq Stockholm for the entire 2006 - 2015 period. Thus, a number of companies were excluded due to bankruptcy, mergers and acquisitions, liquidation, or another potential causes. Paper III uses cross-sectional data on 197 companies, of which 46 had an internal audit function. Non-financial data were manually collected from the annual reports with special emphasis on the internal auditing disclosures. In addition, to the review of the annual reports, it was even in some cases necessary to get access to a separate corporate governance reports located on the companies' websites. In contrast to papers I and III, which use data pertaining to Swedish companies listed on Nasdaq Stockholm, paper II focuses on nonlisted companies. To analyze whether municipal ownership affects and determines the audit fee, it was necessary to collect data from both municipal companies and private companies. More explicitly, the final sample consists of 240 municipal and 249 private companies in the real estate industry. The financial and non-financial data were partially manually collected from the annual reports and also gathered from the Retriever Business database. 
Additionally, five interviews were conducted with partners from the Big 4 audit firms and with Grant Thornton. The data collection for paper IV was described in the previous section.

\section{Operationalization}

As in the majority of previous audit fee studies (e.g. Firth, 1997; Niemi, 2002; Thinggaard \& Kiertzner, 2008), the natural logarithm of the audit fees has been used as the dependent variable in all of the first three papers. ${ }^{4}$ Additionally, paper I measures audit fee cutting and relative fee pressure as: (i) a dummy variable coded as 1 if the percentage change in audit fees is negative and 0 otherwise (Chen, Krishnan, \& Yu, 2018; Krishnan \& Zhang, 2014) and (ii) a dummy variable coded as 1 if the percentage change in audit fees scaled by total assets is negative and 0 otherwise. Regarding the independent variables of the different studies, it was of importance to consider the unique scope of each paper. Overall, the independent variables of the different papers aim to capture: client business risk (paper I), municipal ownership (paper II), and finally the use of an IAF and the specific nature of internal auditing disclosures (paper III). For a further discussion of the independent variables, see the individual papers.

In accordance with Simunic (1980) and the vast majority of subsequent audit fee studies, it was essential to control for client attributes related to client size, client complexity, and client risk. The control variables included in the audit fee papers (papers I-III) were selected according to the unique characteristics of each study and based on the assumption that they affect the audit fees (i.e., audit fee pressure) in different ways. According to their metaanalysis of the audit fee literature, Hay et al. (2006) and Hay (2013), provide evidence that client size is by far the most important driver of audit fees. The size of the client has in previous studies mainly been operationalized by using the total assets at year end (Firth, 1997; Gonthier-Besacier \& Schatt, 2007; Niemi, 2002; Simunic, 1980), or the turnover at year end (Chan et al., 1993; O’Sullivan, 2000). Altogether, in papers I-III client size was operationalized by total assets at year end, though there are concerns that the audit fees and the size of the client follow a non-linear relationship (Cobbin, 2002). In order to improve the linear relationship between the audit fees and the size of the client, transformation was

\footnotetext{
${ }^{4}$ To clarify, paper II (municipal corporations) only includes fees paid to the external auditors and do not include costs related to the work performed by lay auditors.
} 
conducted using the natural logarithm of total assets (Holm \& Thinggaard, 2014). Depending on the available data, client complexity was operationalized, either by considering the total number of subsidiaries (Goodwin-Stewart \& Kent, 2006; Singh et al., 2014) or by using a combination of measures related to the total number of business segments, the ratio of foreign assets to total sales, and foreign employees as a percentage of total employees (Francis, 2005; Kim \& Fukukawa, 2013; Nikkinen \& Sahlström, 2003). Irrespective of the different measures, they all intend to capture organizational complexity and increased monitoring costs. Regarding the inherent risk of the client, inventory and receivables are two types of assets that may need more extensive auditing due to large volumes and an increased risk of manipulation and fraud (Firth, 1997). Early studies operationalized inherent risk by separately dividing inventory and receivables with by total assets (Chan et al., 1993; Firth, 1997; Simunic, 1980). However, more recent studies (even those cited in the appended papers of this thesis) first sum inventory and receivables and then divide them by total assets (Ahmed \& Goyal, 2005; Griffin, Lont, \& Sun, 2009; Niemi 2005). A further proxy for inherent risk that has been used as a control variable is the systematic risk of the company. Clients with greater stock market volatility may be charged with a risk premium due to a higher intrinsic business risk (Nikkinen \& Sahlström, 2003, O’Sullivan, 2000). Client profitability, leverage, use of a financial guarantee, and cashflow divided by total assets are all different measures of client risk that are likely to have an effect on audit fees (André, Broye, Pong, \& Schatt, 2016; Casterella, Francis, Lewis, \& Walker, 2004; Gul \& Tsui, 1998). Thus, it has been vital to control for client risk as it is related to an increased probability of bankruptcy that in the end may have both financial and reputational consequences for the auditor. Finally, following the operationalization used in previous studies focusing on public companies, industry dummies were included in order to control for industry differences (Ettredge et al., 2017; Seetharaman, Gul, \& Lynn, 2002) and ownership control was measured by adding together the voting rights of the five largest shareholders (Axén, 2018).

Regarding different audit firm attributes, multiple studies have provided evidence that Big $\mathrm{N}$ audit firms are associated with higher audit quality, and thus are able to earn an audit fee premium (Craswell et al., 1995; DeFond \& Zhang, 2014; Gist, 1992; Ireland \& Lennox, 2002). Hence, previous studies normally include a dummy variable in order to control for 
whether the client is audited by a Big N audit firm (Caneghem, 2010; Ezzamel, Gwilliam, $\&$ Holland, 2002). However, regarding the nature of the audit market for listed companies in Sweden, it is largely dominated by Big 4 audit firms, which makes it of greater interest to consider differences among each of the Big 4. Consequently, the audit fee papers appended to this thesis have considered individual audit firm effects. Following Numan and Willekens (2012), industry specialization was measured by considering differences in industry specialization among the audit firms. Regarding audit tenure, previous studies support the practice of "low-balling" during the initial years with a new audit firm (Ettredge \& Greenberg, 1990; Simon \& Francis, 1988;). In order to control for the existence of "lowballing" a dummy variable, indicating auditor change, was included in all of the audit fee models (papers I-III).

With regard to engagement attributes, the existence of non-audit fees has been included as a control variable due to its ability to have an impact on audit fees (Bigus and Zimmermann, 2008; Firth, 1997; Köhler \& Ratzinger-Sakel, 2012). On one hand, it is possible to argue that the joint provision of audit and non-audit services results in cost savings due to knowledge spillovers and increased efficiency. On the other hand, the existence of nonaudit fees may impair audit independence as a result of, for example, financial dependence (DeFond, Raghunandan, \& Subramanyam, 2002, Simunic, 1984). Both audit report lag and audit opinion are expected to be related to incremental audit effort and higher audit fees (Basioudis, Papakonstantinou, \& Geiger, 2008, Knechel \& Payne, 2001). Regarding the total number of days between the fiscal year end date of a company and the signing of audit report, it is likely that a greater number of days indicates an increase in operational complexity and that more audit problems (i.e., unexpected circumstances) have been encountered during the audit process (Jaggi \& Tsui, 1999; Knechel \& Payne, 2001). Lastly, in recent years there has been increasing research on individual auditor attributes, related to, for example, audit partner gender, audit partner specialization, number of signing auditors and, audit partner experience and age (Ittonen \& Peni, 2012; Gul, Wu, \& Yang, 2013; Sundgren \& Svanström, 2014; Zerni et al., 2012). Thus, paper I controls for individual auditor attributes by including two different dummy variables, one that captures gender differences and one that controls for the use of more than one signing auditor (see Appendix 1 , for further details). 


\section{The research process}

The research process started at the end of 2013 with the writing of paper I. An early draft of the paper was presented at the Nordic Accounting Conference in Copenhagen in 2014. However, due to the emergence of new research ideas and the writing of additional papers, paper I was put on hold until late 2018. At the beginning of 2019, additional data were gathered and the paper was completely reconstructed with a new aim to examine the determinants of fee cutting and relative fee pressure. Currently, paper I is a working paper that is ready to be sent to a journal for a first round of review. Paper II is co-authored together with my main supervisor Torbjörn Tagesson, and the empirical data were mainly collected by three former students. The first draft of the paper was accepted and presented at the $7^{\text {th }}$ Workshop on Accounting and Regulation in Siena, in 2016. After further feedback from colleagues and multiple rounds of review, paper II was accepted for publication in the Journal of Management and Governance in 2018 and finally published in 2019.

Regarding paper III (single-authored), the research process started in 2015 when an initial research idea was presented at a round table session at the Ph.D. workshop of the $8^{\text {th }}$ EARNet symposium in Lausanne. During the following year, a full-length version of the paper was written and presented at the $39^{\text {th }}$ EAA Annual Congress in Maastricht and subsequently submitted to a journal. After a demanding review process involving the gathering of new data and valuable and constructive comments from the anonymous referees, paper III was accepted and published in the International Journal of Auditing in 2018. Paper IV is co-authored with my supervisor Pernilla Broberg. The research topic in paper IV emerged from the work on paper III and its focus on voluntary disclosures. Empirical data (interviews) were gathered during the spring of 2019, and in its current form it is a full-length working paper. The research process is visually presented in Figure 3. 


$\begin{array}{lllllll}2013 & 2014 & \text { Year } & & \\ 2015 & 2016 & 2017 & 2018 & 2019\end{array}$

Paper I

Paper II

Paper III

Paper IV
Working paper

\section{Published paper}

\section{Published paper}

Working paper

Figure 3: Research process 


\section{Chapter 4}

\section{Summary of papers}

\section{Paper I}

Axén, L. (2019). Determinants of fee cutting and relative fee pressure: A client business risk perspective. Working paper.

The objective of this study is to examine the determinants of fee cutting and relative fee pressure with special emphasis on the financial aspects of the company. Prior literature provides evidence supporting a negative association between audit fee pressure and audit quality (Beardsley et al., 2019; Christensen et al., 2014; Ettredge et al., 2014; Ettredge et al., 2017). Despite the importance of prior findings, the actual determinants of fee cutting and fee pressure remain largely unexplored (Ettredge \& Greenberg, 1990). Few empirical studies have explored which companies are successful in putting fee pressure on the auditor or are able to receive actual fee cuts. The financial aspects of the companies are the main focus in this study due to their strong association with client business risk and the pricing of audit services (O'Keefe et al., 1994; Simunic, 1980). It is possible to argue that companies with a higher business risk are able to put pressure on the auditor to reduce the audit fees. As a response to lower audit fees, auditors may reduce budgeted audit hours (Bierstaker \& Wright, 2001; Margheim \& Kelly, 1992), assign less experienced and less specialized staff (Beardsley et al., 2019), and shift work offshore (Downey, 2018). However, given previous findings, it is more likely that clients with an increased business risk would be less able to exert fee pressure or receive actual fee cuts. According to previous research, financially distressed clients tend to engage in earnings management (DeFond \& Jiambalvi, 1994; Rosner, 2003; Roychowdhury, 2006) and generally have an increased risk 
of going bankrupt (Firth, 1997). Furthermore, auditors normally respond to increased business risk either by increasing audit effort (i.e., increasing audit hours or using more experienced staff) and/or charging a risk premium to cover potential losses (Bell et al., 2001; Kim \& Fukukawa, 2013; Niemi, 2002).

The empirical data cover 123 listed companies on Nasdaq Stockholm between the financial years 2006 and 2015, resulting in 1230 company-year observations. According to the findings of both the univariate and multivariate analyses, companies that receive fee cuts are more likely to be financially distressed and have a higher client business risk. Based on the strategic management literature (Hofer, 1980; Sudarsanam \& Lai, 2001; Trahms, Ndofor, \& Sirmon, 2013) and the concept of cost retrenchment, financially distressed companies are often keen to find short-term solutions to improve their profitability and company performance. As an initial turnaround strategy, companies will try to reduce a wide range of indirect costs (Morrow, Johnson, \& Busenitz, 2004; Sudarsanam \& Lai, 2001) and arguably even put pressure on the auditor to lower the external audit fees. However, when measuring audit fee pressure as the ratio of audit fees to the total assets, the results are overall consistent with the hypothesis and support the notion that a negative association exists between client business risk and relative audit fee pressure. In line with previous studies focusing on audit production (O'Keefe et al., 1994, Schelleman \& Knechel, 2010), the results may be explained by the fact that a lower business risk makes it possible to perform the audit more efficiently, so financially stronger companies are more likely to exert a relative fee pressure. Overall, the contradictory regression results reveal that the determinants of fee cutting and relative fee pressure differs depending on the proxies used, and that the financial aspects of the client are of great importance. This study contributes to the literature by examining the determinants of fee cutting and relative fee pressure within a low-litigation environment. 


\section{Paper II}

Axén, L., Tagesson, T., Shcherbinin, D., Custovic, A., \& Ojdanic, A. (2019). Does municipal ownership affect audit fees. Journal of Management and Governance, 23(3), 693-713.

The aim of this study is to analyze whether municipal ownership affects and determines audit fees. Prior studies (Collin et al., 2017; Simunic, 1980; Sundgren \& Svanström, 2013) have examined the determinants of audit fees within a wide range of organizational forms, i.e., public corporations, private corporations, and municipalities, however, this study extends prior research by focusing on a new organizational form, namely, municipal corporations. In the wake of public sector reforms in the 1980s and 1990s (inspired by new public management), municipalities reduced their direct management by integrating different market mechanisms and management concepts from the private sector (Almqvist et al., 2013, Hood, 1885). The emergence of different hybrid organizations, blending publicand private-sector features, created a need to handle demands from a wide range of stakeholders (Grossi et al., 2017; Kickert, 2001). Thus, the governance of municipal companies is rather complex, and an accountability gap exists as accountability is claimed from both the democratic and market perspectives (Grossi \& Thomasson, 2015; Sands, 2006). From an audit viewpoint, it is possible to argue that municipal corporations will pay higher audit fees than will private corporations, for example, due to: (i) greater reputational risk related to their political affiliation and a high public viability; (ii) the fact that a partly parallel audit by lay auditors may detect mistakes not found by the auditors, which may force auditors to increase audit effort; and (iii) a prohibition on allocating assets to other geographic areas makes it difficult for municipal corporations to pursue a diversification strategy that can be used to decrease the overall business risk (Boverket, 2017; Redmayne et al., 2010; SALAR, 2013; Viezer, 2000). However, in contrast to previous claims, it is possible to argue that municipal corporations will be charged lower audit fees due to having financially strong owners (leading to extremely low risk of bankruptcy) and a reduced accountability within municipal corporations that decreases the litigation risk (Collin \& Tagesson, 2010; Grossi \& Thomasson, 2015; Sherer \& Turley, 1997). 
The audit fee model is tested on a matched sample of 249 municipally owned companies and 240 private companies in the real estate industry. Most of the data were collected from annual reports for the year 2012, while additionally data were gathered from the Retriever Business database. In addition to the statistical analysis, five interviews were conducted with partners from the Big 4 audit firms and from Grant Thornton. A sequential explanatory strategy with follow-up interviews made it possible to improve the validity of the results and to further interpret the quantitative findings (Creswell, 2009; Patton, 2002). According to the results of this study, municipal corporations pay significantly lower audit fees than do private companies. In addition to previous reasons related to the low risk of bankruptcy, reduced accountability, and decreased litigation risk, another possible explanation for the observed fee difference is that municipal corporations are able to push down audit fees as a result of the procurement process. This paper contributes to the audit fee literature by adding evidence from a new organizational form, namely, municipal corporations. The results indicate that the explanatory power of the audit fee model is reduced when shifting the focus from listed to privately and municipally owned companies.

\section{Paper III}

Axén, L. (2018). Exploring the association between the content of internal audit disclosures and external audit fees: Evidence from Sweden. International Journal of Auditing, 22(2), 285-297.

The aim of this study is to explore the content of internal audit (IA) disclosures in annual reports and to explain the relationship between IA disclosures and external audit fees. The IA function is an essential governance mechanism that holds a unique position within the organization. It serves as an important resource for a number of stakeholders, such as senior management, the audit committee, and external auditors (Andersson \& Christ, 2014; Gramling et al., 2004; Prawitt et al., 2011). However, despite the importance of the IA function, there are no regulatory reporting requirements that force companies to disclose information about the IA and reduce the information asymmetry between corporate insiders and outside investors (Archambeault, DeZoort, \& Holt, 2008). As an alternative, managers have the opportunity to improve their governance transparency by disclosing information about internal auditing on a voluntary basis. Previous research provides evidence that 
companies with more informative disclosures possess superior governance quality (Beekes \& Brown, 2006) and are more likely to make actual investments in disclosed activities (Toms, 2002). Hence, it is logical to argue that companies with more informative IA disclosures will have a higher IA function quality, which can be expected to have an impact on the external audit fees. Prior research into the association between IA function quality and external audit fees has shown mixed results (Zain et al., 2015; Gros et al., 2017), so it is possible to argue for either a negative or positive relationship between informative IA disclosures and the external audit fees.

This study uses cross-sectional data on 197 companies listed on Nasdaq Stockholm in 2013. Of all the companies included in the study, 46 had implemented an IA function by the end of 2013. Data for this study were mainly obtained from the annual reports, and additional financial data were collected from databases and the Swedish magazine Aktiespararen. As the aim of this study was to explore the content of internal audit disclosures in annual reports, a content analysis was used as a research method in order to classify the internal audit disclosures into categories and investigate variation in disclosure practice. Due to a lack of previous research considering the practice of internal auditing disclosures, it was necessary to use an inductive categorization process, with a primary focus on understanding the empirical data (Hsieh \& Shannon, 2005; Mayring, 2000). According to the results of the content analysis, there is a considerable heterogeneity in IA disclosure practice and only a small portion of all IA disclosures are firm specific. This study supports previous findings (Anderson \& Zéghal, 1994; Goodwin-Stewart \& Kent, 2006; Singh \& Newby, 2010) that the use of an IAF is associated with higher audit fees. However, considering the association between informative IA disclosures (firm-specific disclosures) and external audit fees, this study provides contrary evidence that companies with more informative firm-specific IA disclosures are charged lower audit fees than are other companies in the sample. One possible explanation is that companies with more firm-specific disclosures have higher IAF quality, which can reduce the time and effort required by external auditors and hence result in lower audit fees (Prawitt et al., 2011). This study contributes to the audit fee literature by exploring IA disclosures using a content analysis and by using evidence from another corporate governance context than those used by previous studies. 


\section{Paper IV}

Axén, L., \& Broberg, P. (2019). The creation and control of annual report disclosures: Exploring the role and tasks of the project manager. Working paper.

This study focuses on the authorship of annual reports by exploring the management of corporate disclosures. Most empirical studies to date have investigated managers' voluntary disclosure choices and their financial reporting decisions (Beyer et al., 2010; Healy \& Palepu, 2001); however, relatively little field-based research has focused on the actual disclosures process (Gibbins et al., 1990). Using equivalent grounded theory approaches, prior research by Gibbins et al. (1990), Holland and Stoner (1996), and Holland (2005) has developed different theoretical models aiming to explain and predict how companies manage their corporate disclosures. The developed disclosure models are rather general in nature as they consider both organizational and environmental factors influencing the disclosure outputs (Adams, 1997; Holland \& Stoner, 1996). The empirical material in this study consists of semi-structured interviews with corporate managers and the partners of communication companies. Specifically, nine interviews were conducted with senior managers (i.e., investor-relations managers, corporate communication managers, and one CEO) working in large-cap companies listed on Nasdaq Stockholm, and three interviews were conducted with partners and owners of communication agencies. The respondents were selected with regard to the principles of representativeness and quality (Alvesson, 2011), so it was essential to select respondents working in companies operating in a variety of industries. Most interviews were conducted by telephone and recorded by the interviewer.

According to the findings of this study, the project managers responsible for the annual reports perceived that they have considerable freedom of action and a great opportunity to be influential during the complete reporting process. In many cases the project managers act as the main authors of the voluntary corporate disclosures and hence are able to both create and control the disclosed information. The total number of actors involved in the production of the annual report is heavily influenced by the project manager's knowledge, skills, personal characteristics, and view of her/his role and task. Furthermore, the findings illustrate that a wide range of factors influence the disclosure process, and they have been 
categorized into themes related to the project manager's experience, view of the project and her/his own role, and perception of the annual report, as well as to other key actors and influences. This study provides new input to the disclosure literature by exploring the role of the project manager in the preparation of the annual report. 


\section{Chapter 5}

\section{Discussion}

\section{Determinants of audit fees}

\section{Client business risk}

Overall, prior research has demonstrated that client business risk is an important determinant of audit fees (Cobbin, 2002; Hay et al., 2006). According to auditing standards (ISA 315, ISA 330), the assessment of client business risk forms the basis for designing audit plans and greatly influences the nature of subsequent audit procedures. The client's business risk is related to the possibility that the client may fail to meet its objectives, which in the end may lead to going-concern problems (Bell et al., 2008; Erickson et al., 2000). Auditors may respond to higher client business risk either by increasing audit effort and/or by charging a risk premium to cover potential losses (Kim \& Fukukawa, 2013; O'Keefe et al., 1994; Niemi, 2002). Irrespective of the option chosen, it is evident that there exists a positive association between client business risk and audit fees (Hay, 2013). It is important to note that the appended papers in this thesis focuses on different financial conditions of the companies, so the concept of client business risk is restricted to financial aspects and is not based on the auditor's own risk assessments. According to the findings of papers I and paper III, the audit fees of companies listed on Nasdaq Stockholm are determined by different client business risk factors. Regarding the occurrence of financial losses, the regression results suggest a significant positive relationship between financial losses and audit fees. These results are in line with those of Hay et al. (2006), whose meta-analysis emphasizes that financial losses have become a variable of increasingly importance when explaining and determining audit fees. Furthermore, in paper I it is evident that companies 
with poor financial performance (measured as return on assets and operating cash flow divided by total assets) and a high risk of bankruptcy (predicted by Zmijewski's bankruptcy model) will be charged with higher audit fees. One possible explanation for the regression results is that companies that are financially distressed generally have an increased risk of going bankrupt, which will have negative consequences for both shareholders and auditors (Firth, 1997). According to previous research (DeFond \& Jiambalvo, 1994; Rosner, 2003; Roychowdhury, 2006), financially distressed clients have incentives to engage in earnings management in order to present an overly positive view of their business activities and financial position. Hence, auditors may carry out additional audit tests in order to respond to an increased risk of material misstatement and to protect themselves from ex post losses, for example, due to potential lawsuits from different investor groups (Simunic \& Stein, 1996). There is no evidence that the systematic risk (beta value) of listed companies is a factor determining the audit fees. One explanation may be that the beta coefficients of smaller companies can be biased due to infrequent trading, which impairs their comparability to those of more frequently traded companies (Bartholdy \& Riding, 1994). Regarding paper II and its sample of companies in the real estate and housing industry, there is no evidence that the included risk variables are positively related to the audit fees; instead, contradictory evidence is provided that the debt-to-equity ratio is negatively associated with the audit fees. One possible explanation is that the sample is restricted to one specific industry with unique characteristics that have an impact on the results. Overall, the results of the different audit fee models support the importance of client business risk when determining the audit fees for listed companies, but not for private and municipal companies, in the real estate and housing industry.

Paper I extends prior research by examining the determinants of fee cutting and relative fee pressure, with special emphasis on the financial aspects of the company. Overall, prior research has demonstrated that client business risk is an important determinant of audit fees (Cobbin, 2002; Hay et al., 2006), so it is logical to argue that the financial aspects of the company (part of the business risk) may be related to the ability to put pressure on the auditor to reduce the audit fees. According to the findings of paper I, both the univariate and the multivariate analyses support the notion that companies receiving fee cuts are more likely to be financially distressed and have higher client business risk. Previous findings in 
the strategic management literature (Hofer, 1980; Sudarsanam \& Lai, 2001; Trahms et al., 2013) suggest that financially distressed companies are keen on finding short-term solutions in order to improve their profitability and company performance. By using a cost retrenchment strategy, financially distressed companies will try to reduce their indirect costs (Sudarsanam \& Lai, 2001; Morrow et al., 2004); consequently, they may also pressure the auditor to reduce the external audit fees. Considering the practice of low-balling (DeAngelo, 1981a), it is possible to argue that auditors may be willing to temporarily reduce the audit fees (thus in this case not triggered by an audit firm rotation) and charge fees below the marginal cost of an audit, as they plan to earn quasi-rents in subsequent years. However, when considering relative fee pressure, the results are contradictory and support the notion that there exists a negative association between client business risk and relative audit fee pressure. In line with previous findings (Bell et al., 2001; Kim \& Fukukawa, 2013; Niemi, 2002), it is logical to argue that financially strong companies with lower business risk will be more likely to exert a relative fee pressure, as they may require less audit effort and/or can be charged with a lower risk premium. In sum, the determinants of fee cutting and relative fee pressure differ considerably, especially with regard to the financial aspects of the company.

\section{Municipal ownership}

The pricing of audit services has been extensively studied in the archival literature, and the original audit fee model developed by Simunic (1980) has been applied to a wide range of different organizational forms: listed companies (André et al., 2016; Craswell et al., 1995; Holm \& Thinggaard, 2014), private companies (Hope \& Langli, 2010; Sundgren \& Svanström, 2013), and public-sector organizations (Collin et al., 2017; Johnsen et al., 2004). Each organizational form has its own characteristics and can differ due to, for example, varying degrees of agency conflict, varying ownership structures, different aims and objectives, different types of legislation, and different levels of accountability (Billis, 2010; Langli \& Svanström, 2014; Vanstraelen \& Schelleman, 2017). This thesis adds evidence from a new organizational form namely, municipal corporations. Municipal corporations can be regarded as hybrid organizations in which both public and private characteristics are combined, and conflicting goals and stakeholder demands are the norm (Grossi et al., 2017; Lindqvist, 2013). According to the findings of paper II, municipal corporations pay 
significantly lower audit fees than do private companies in the same industry. Lower audit fees within municipal corporations may be explained by the fact that municipal corporations, in comparison with private corporations, are longer-term in their investment strategies and acquire and sell properties to a lesser extent (Boverket, 2017). Changes in corporate structure (i.e., due to mergers and acquisitions) would likely create increased demand for additional auditing, as auditors need to obtain an understanding of the new entity in order to identify and assess risks of material misstatement of the financial statements (ISA, 315). It is even rational to argue that reduced accountability in municipal corporations (Grossi \& Thomasson, 2015) creates an opportunity for auditors to act in their own self-interest and perform an audit of lower quality. According to the interviews (used in further interpreting the statistical results), lower business risk in municipal corporations and a competitive procurement process are two possible explanations for why audit fees are lower in municipal corporations. Overall, the empirical results indicate that audit firms put more emphasis on business risk and litigation risk factors, compared with reputational aspects, when pricing audit engagements with municipal corporations.

Initially, the audit fee model was developed to investigate the existence of monopolistic pricing within the U.S. audit market and based on data pertaining to public companies. Hence, the fundamental assumptions underlying the audit fee model and its basic logic are based on different factors that have an effect on the total audit fees of public companies. Previous research (Alexeyeva \& Svanström, 2015; Cobbin, 2002; Zerni et al., 2012) provides evidence that the overall explanatory power of the audit fee model for public companies is high, commonly around $80-90 \%$. However, the explanatory power is reduced, normally to around 50-55 \%, when considering private companies (Hope \& Langli, 2010; Sundgren \& Svanström, 2013). As recognized in the literature, there are fundamental differences between public and private companies; greater heterogeneity in the private sector reduces the audit fee model's predictive ability and a substantial share of the variation of audit fees remains unexplored (Langli \& Svanström, 2014). Considering the findings of paper II, the explanatory power is further reduced when shifting focus from private to municipal companies. The audit fee model of municipal companies has an explanatory power of around $40 \%$, which can be compared with $50-55 \%$ for private companies and 80 - 
90\% for public companies. Hence, the audit fee model for municipal companies could be further developed to better capture the specific nature of hybrid organizations.

\section{Internal auditing}

The internal audit function (IAF) acts as a key component of a company's corporate governance system (Gramling et al., 2004) and it "provides valuable inputs and guidance to the board, management, and the external auditors, who help facilitate effective governance processes" (Anderson \& Christ. p, 231). Prior research investigating the relationship between internal auditing and audit fees has found mixed results (Goodwin-Stewart \& Kent, 2006; Gros et al., 2017; Zain et al., 2015), and two competing perspectives (substitution versus complementary) have emerged in the literature. According to previous findings (Felix et al., 2001; Gros et al., 2017; Prawitt et al., 2011), the IAF can be regarded, at least in part, as a substitute for external audit. From a substitution perspective, the work of internal auditors may contribute to the improvement of internal controls, which can reduce the total amount of evidence that is needed from substantive procedures (performed by external auditors) and thus also reduce the external audit fees (Wallace, 1984; Prawitt et al., 2011). Regarding the empirical findings of paper III, the use of an IAF is associated with higher external audit fees, so a substitution perspective is not supported. Instead, the results of paper III are consistent with previous findings (Anderson \& Zéghal, 1994; GoodwinStewart \& Kent, 2006; Hay et al., 2008) and support the view of a complementary relationship. From a complementary perspective it is possible to argue that companies that believe in a strong corporate governance practice are likely to invest resources in both internal and external audits (Goodwin-Stewart \& Kent, 2006). Furthermore, work undertaken by the IAF will create a large number of internal audit reports and reviews that will likely increase the workload of external auditors, who will need to spend time and effort reviewing them (Zain et al., 2015). Prior research by Hay et al. (2008) argues that a wide range of different governance mechanisms (e.g., internal auditing, external auditing, and audit committees) can be used and combined in order to protect the reputation of independent directors and uphold public confidence.

Given prior findings, companies with more informative disclosures possess superior governance quality (Beekes \& Brown, 2006) and are more likely to make actual investments in disclosed activities (Toms, 2002). Furthermore, subsequent research by Boskou, Kirkos, 
and Spathis (2019) provides empirical evidence indicating that text analysis of IA disclosures can be used to predict IAF quality. Thus, consistent with these findings, paper III examines the relationship between internal auditing disclosures and the external audit fees by using firm-specific disclosures as a proxy for IAF quality. According to the empirical results, clients with more transparent firm-specific disclosures related to internal auditing pay lower audit fees than do firms not providing such disclosures. One possible explanation is that higher IAF quality (i.e., use of firm-specific disclosures) will positively affect the external auditor's reliance on the IAF and improve the efficiency and effectiveness of the external audit (Bame-Aldred et al., 2013). Hence, improved audit efficiency due to a higher IAF quality will be associated with lower external audit fees (Gros et al., 2017). In sum, the results of this study extend previous IAF research (Prawitt et al., 2011; Zain et al., 2015) by providing novel evidence that firm-specific IA disclosures are likely to represent actual investments in IA and hence can be used as a proxy for IAF quality.

\section{Corporate disclosures}

In the accounting literature, much previous research has investigated different determinants of corporate disclosures and managers' financial reporting choices (Beyer et al., 2010; Healy \& Palepu, 2001). Regarding voluntary disclosures, managers have incentives to disclose information that they believe is relevant and useful to external stakeholders (Meek et al., 1995), as it may increase transparency to the capital market and finally lower the cost of capital (Diamond \& Verrecchia, 1991; Healy \& Palepu, 2001). Paper III focuses on voluntary disclosures related to internal auditing (IA) and investigates variation in disclosure practice by conducting a content analysis. According to the empirical results, there exists a large variation in disclosure practice and only a small portion (15\%) of all IA disclosures contains information that is firm specific. Specifically, firm-specific disclosures can be both quantitative and qualitative in nature, highlighting specific target areas, the total number of internal auditors, and performed internal audits. Overall, firm-specific IA disclosures commonly contain some kind of information that could be connected to actual investments in IA. The small number of firm-specific IA disclosures may be explained by the fact that disclosures based on quantitative data and verifiable events require an actual commitment to disclosed activities and actual investments that is costly to achieve (Toms, 2002). 
In the accounting literature, much previous research has investigated different determinants of corporate disclosures and managers' financial reporting choices (Beyer et al., 2010; Healy \& Palepu, 2001), though relatively little field-based research has focused on the actual disclosures process (Gibbins et al., 1990). The authorship of corporate disclosures is largely unknown and few studies have explored the actors involved in the disclosure process (Beattie, 2014; Merkle-Davies \& Brennan, 2007). Paper IV provides new insight into the process of crafting annual reports by conducting interviews with responsible project managers. The interviewed project managers perceive that they have a high degree of decision latitude and autonomy in their role as being responsible for the creation of the annual report. Considerable freedom of action gives the project leaders an opportunity to be highly influential in the production of the annual report, in many cases acting as the main author of the voluntary corporate disclosures. Hence, the actual number of actors/authors involved in the disclosure process is heavily influenced by the project manager's knowledge, skills, personal characteristics, and the view of her/his role and task. According to the empirical findings, a wide range of factors influence the disclosure process, and they were categorized into themes related to the project manager' experience, view of the project and her/his own role, and perception of the annual report, as well as to other key actors and influences. Overall, many factors are directly or indirectly linked to the mission and personal characteristics of the project managers. On the basis of the interviews, we also identify different types of project leaders distinguished by their actual involvement as authors, their view of involving other colleagues, and their own beliefs with regard to creating and controlling information. 


\section{Chapter 6}

\section{Contributions, limitations and future research}

\section{Determinants of audit fees}

This thesis makes several contributions to the audit literature. First, the results of this thesis extend prior audit fee literature (Hay et al., 2006; Hay, 2013) by adding evidence from a new organizational form, namely municipal companies. Despite the fact that municipal corporations play an important role in the Swedish economy (Bergh et al., 2019; Erlingsson et al., 2015), they have been largely neglected in the audit fee literature, and this thesis contributes to a more thorough understanding of audit pricing in municipal corporations. More specifically, this thesis demonstrates that municipal corporations have specific characteristics (compared with private corporations), which in turn have an effect on the external audit fees and also gradually impairs the predictability of the traditional audit fee model. Furthermore, in response to Simnett et al. (2016) and their call for organizational and institutional pluralism within archival fee studies, this thesis has investigated the determinants of audit fees in a variety of different organizational forms. The empirical findings of this thesis show that the explanatory power of the audit fee model is progressively reduced when shifting focus from public companies to private companies and, lastly, to municipal corporations. Hence, according to the results of this thesis, it is of great importance to consider the unique characteristics of the organizational form when determining the audit fees.

Second, prior literature on audit fee pressure and fee cutting has mainly focused on the association with audit quality (Beardsley et al., 2019; Christensen et al., 2014; Ettredge et al., 2014; Ettredge et al., 2017). This thesis extends previous research by examining the 
actual determinants of fee cutting and fee relative pressure. In particular, the empirical findings of this thesis indicate that the determinants of fee cutting and relative fee pressure differs considerably, especially with regard to different client business risk factors. Furthermore, in line with the strategic management literature (Hofer, 1980; Sudarsanam \& Lai, 2001; Trahms et al., 2013) this thesis supports the idea that financially distressed clients will identify various opportunities for cost savings e.g. by pressure the auditor to reduce the external audit fees. Third, this thesis extends prior IAF quality research by providing results indicating that firm-specific internal auditing disclosures can be used as a proxy for IAF quality. Shareholders, policymakers, and managers are all likely to be interested in the practical implications of the present results. By disclosing more firm-specific information related to actual investments in internal auditing, managers are able to differentiate their companies (by promoting superior IAF quality) from other companies not genuinely committed to internal auditing. This thesis also contributes to the IAF quality literature by using an alternative research method (content analysis) beyond the experimental and survey approaches used in prior research (Gramling et al., 2004). Fourth, the empirical findings from of this thesis provide evidence from a Nordic context that differs significantly from that provided by previous studies conducted in common law countries (Ettredge et al., 2014; Goodwin-Stewart \& Kent, 2006; Prawitt et al., 2011). Specifically, the Nordic context is characterized as a low-litigation environment with a more concentrated ownership structure than that prevalent in common law countries (Niemi et al., 2018; Sundgren \& Svanström, 2013). Furthermore, Nordic listed companies are characterized by having a high degree of transparency towards their shareholders and the general meeting has an extensive governance power (Gabrielsson, 2012; Lekvall, 2014).

\section{Corporate disclosures}

Considering the aim to improve our understanding of how companies manage their corporate disclosures, this thesis makes several contributions to the accounting and audit literature. First, the evidence provided in the thesis contributes to the literature (Archambeault et al., 2008; Holt \& DeZoort, 2009) by exploring the content of internal auditing disclosures in annual reports. The findings of this thesis are important as they demonstrate that listed companies vary widely in their disclosure practice and that only a small portion of all internal auditing disclosures contain firm-specific information. Hence, 
the results provide insight and guidance to regulators and standard setters that it may be useful to implement regulatory reforms encouraging companies to depart from standardized and generic disclosures.

Second, this thesis contributes to the disclosure literature by uncovering the role of the project manager in the preparation of the annual report. Previous research has highlighted a lack of transparency regarding corporate disclosures, so there is a great need to better understand the disclosure process and identify the involved actors (Beattie, 2014; MerkleDavies \& Brennan, 2007). The results of paper IV indicate that the project manager is highly influential in the production of the annual report and in many cases acts as the main author of the voluntary corporate disclosures. Moreover, this thesis challenges the perception that company executives are the main actors involved in the preparation of the annual report. Third, this thesis extends prior field-based research by considering the preparation of the entire annual report and not only the financial (Gibbins et al., 1990; Holland \& Stoner, 1996), and continuous disclosures (Mayorga, 2013). By taking a more holistic perspective, is has been possible to identify a wide range of new factors influencing the final disclosure output, factors not found in previous studies. Fourth, this thesis goes beyond the traditional view of the disclosure process by including the perspective of the communication agencies.

\section{Limitations}

The results of this thesis should be viewed in the light of certain limitations. First, the audit fee model is based on two basic elements, portioned into production costs and expected future losses (Simunic, 1980). This duality limits the interpretability of the results, as an increase in audit fees can be attributed to a higher production cost and/or the charge of an additional risk premium. Furthermore, audit fees reflect a complex interdependence among both supply and demand factors (Defond \& Zhang, 2014), and are affected by interactions among various components of the audit market (Causholli et al., 2010). Second, the sample of paper I it is based on companies listed on Nasdaq Stockholm for the entire period of study (2006-2015). This restriction may cause potential selection bias, as the sample chosen is probably more homogenous than the total population. The use of an unbalanced panel (allowing for both the entry and exit of companies) could have partially mitigated potential selection bias. Furthermore, the sample of paper II is restricted to companies in the real estate and housing industry, limiting the generalizability of the results to other industries. 
Third, the audit fee model used in paper II was mainly developed with regard to private companies and may not reflect the unique characteristics of municipal corporations. According to Redmayne et al.'s (2010) interviews and indicative findings, political visibility is of importance when pricing audit services for municipal corporations and may hence be used as a control variable. Fourth, in paper III it might have been beneficial to use panel data instead of cross-sectional data in order to obtain more robust results. However, the categorization process was highly time consuming and limited the possibility of including data for more years. A disclosure index could advantageously be developed that measures the overall IAF quality by assessing the informativeness of internal auditing disclosures. Fifth, the findings of paper IV are based upon the beliefs of a single company manager at each company. It might have been beneficial to interview a variety of several managers at each company, as it is possible to argue that different managers have different viewpoints, even though that they belong to the same organization. However, all interviews were conducted with highly skilled managers (project leaders of the annual reports) in a senior position in each company. Lastly, the respondents in paper IV belong to large companies with market capitalization exceeding EUR 1 billion, which may have influenced the interpretation of the findings.

\section{Future research}

Since the seminal work by Simunic (1980), many subsequent studies have used and refined the original audit fee model in order to explore different determinants of audit fees (Hay et al., 2006; Hay, 2013). Developed versions of the audit fee model have been applied to different organizational forms (Baber, 1983; Holm \& Thinggaard, 2014; Sundgren \& Svanström, 2013); however, with regard to municipal corporations, the model could be developed further. By developing the audit fee model, future research could better capture the specific characteristics of municipal organizations and adapt to the inherent complexity of hybrid organizations.

Another promising avenue for future research would be to examine the effect of fee pressure on auditor's decision making. In line with prior research by Houston (1999), there is a need to understand how auditors respond to the joint effects of fee pressure and increased client business risk. For example, how will fee pressure affect the total number of budgeted hours and the extent of planned audit procedures? This thesis has examined the relationship 
between internal auditing disclosures and the external audit fees by using firm-specific disclosures as a proxy for IAF quality. Future research could usefully investigate the relationship between internal audit disclosures and IAF quality by combining different research methods (e.g., archival methods, survey methods, and interviews). Survey data on internal auditing characteristics (i.e., the size of the internal auditing budget, the competence and experience of the internal auditors and, the average number of training days) could beneficially be used to operationalize IAF quality. Furthermore, semi-structured interviews with internal auditors and those involved in the disclosure process would enhance our understanding of disclosure practice and reveal the actual decisions underlying the disclosure of firm-specific information related to internal auditing. Furthermore, additional evidence is needed from other institutional settings outside Sweden.

A potentially interesting avenue for future research would be to use a case study approach (in line with Frostenson \& Helin, 2017) to improve our understanding of the different actors participating in the disclosure process and their impact on decision making regarding corporate disclosures. Furthermore, there is a need to examine the relationship between disclosure practice and corporate disclosure quality. 


\section{References}

Abdel-Khalik, A.R. (1993). Why Do Private Companies Demand Auditing? A Case for Organizational Loss of Control. Journal of Accounting, Auditing and Finance, 8, 3152.

Aberbach, J., \& Rockman, B. (2002). Conducting and coding elite interviews. Political Science and Politics, 35(4), 673-676.

Abrahamson, E., \& Park, C. (1994). Concealment of negative organizational outcomes: An agency theory perspective, Academy of Management Journal, 37(5), 1302-1334.

Adams, M. (1997). Ritualism, opportunism and corporate disclosures in the New Zealand life insurance industry: field evidence. Accounting, Auditing \& Accountability Journal, 10(5), 718-738.

Aerts, W. (2001). Inertia in the attributional content of annual accounting narratives, European Accounting Review, 10(1), 3-32.

Aerts, W. (2005). Picking up the pieces: Impression management in the retrospective attributional framing of accounting outcomes, Accounting, Organizations and Society, 30, 493-517.

Ahmed, K., \& Goyal, M. (2005). A comparative study of pricing of audit services in emerging economies. International Journal of Auditing, 9(2), 103-116.

Akono, H., \& Stein, M. (2014). Estimating audit fees and production models. Ch. 22. In Hay, D., Knechel, R.W., \& Willekens, M. (Eds.), Routledge Companion to Auditing (pp.276-286). Routledge: Abingdon and New York.

Alexeyeva, I., \& Svanström, T. (2015). The impact of the global financial crisis on audit and non-audit fees. Managerial Auditing Journal, 30, 302-321.

Alexius, S., \& Grossi, G. (2018). Decoupling in the age of market-embedded morality: responsible gambling in a hybrid organization. Journal of Governance and Management, 22, 285-313.

Almqvist, R., Grossi, G., van Helden, G.J., \& Reichard, C. (2013). Public sector governance and accountability. Critical Perspectives on Accounting, 24(7-8), 479-487. 
Alvesson, M. (2011). Interpreting interviews. London, SAGE Publications Ltd.

Anderson, U., \& Christ, M. (2014). Internal audit. Ch. 18. In Hay, D., Knechel, R.W., \& Willekens, M. (Eds.), Routledge Companion to Auditing (pp.230-239). Routledge: Abingdon and New York.

Anderson, T., \& Zéghal, D. (1994). The pricing of audit services: Further evidence from the Canadian market. Accounting and Business Research, 24(95), 195-207.

André, R. (2010). Assessing the accountability of government-sponsored enterprises and quangos. Journal of Business Ethics, 97(2), 271-289.

André, P., Broye, G., Pong, C., \& Schatt, A. (2016). Are joint audits associated with higher audit fees? European Accounting Review, 25(2), 245-274.

Archambeault, D., DeZoort, T., \& Holt, P. (2008). The need for an internal auditor report to external stakeholders to improve governance transparency. Accounting Horizons, 22(4), 375-388.

Armitage, S., \& Marston, C. (2008). Corporate disclosure, cost of capital and reputation: Evidence from finance directors. The British Accounting Review, 40, 314-336.

Ashforth, B.E., \& Gibbs, B.W. (1990). The double-edge of organizational legitimation. Organization Science, 1, 177-194.

Axén, L. (2018). Exploring the association between the content of internal audit disclosures and external audit fees: Evidence from Sweden. International Journal of Auditing, 22(2), 285-297.

Axén, L., Tagesson, T., Shcherbinin, D., Custovic, A., \& Ojdanic, A. (2019). Does municipal ownership affect audit fees. Journal of Management and Governance, 23(3), 693-713.

Baber, W.R. (1983). Toward understanding the role of auditing in the public sector. Journal of Accounting and Economics. 5(3), 213-227.

Baginski, S.P., Hasell, J.M., \& Hillison, W.A. (2000). Voluntary causal disclosures: Tendencies and capital market reaction. Review of Quantitative Accounting and Finance, 15(4), 371-389. 
Balsam, S., Krishnan, J., \& Yang, J.S. (2003). Auditor industry specialization and earnings quality. Auditing: A Journal of Practice \& Theory, 22(2), 71-97.

Bame-Aldred, C.W., Brandon, D.M., Messier, W.F., Rittenberg, L.E., \& Stefaniak, C.M. (2013). A summary of research on external auditor reliance on the internal audit function. Auditing: A Journal of Practice \& Theory, 32(1), 251-286.

Bartholdy, J., \& and Riding, A. (1994). Thin trading and the estimation of betas: the efficacy of alternative techniques. Journal of Financial Research, 17(2), 241-254.

Basioudis, G.I., Papakonstinou, E., \& Geiger, M.A. (2008). Audit fees, Non-Audit Fees and Auditor Going-Concern Reporting Decisions in the United Kingdom. ABACUS, 44(3), 284-309.

Battilana, J. (2018). Cracking the organizational challenge of pursuing joint social and financial goals: Social enterprise as a laboratory to understand hybrid organizing. M@n@gement, 21(4), 1278-1305.

Battilana, J., \& Dorado, S. (2010). Building sustainable hybrid organizations: the case of commercial microfinance organizations. Academy of Management Journal, 53(6), 1419-1440.

Beardsley, E., Lassila, D., \& Omer, T. (2019). How Do Audit Offices Respond to Audit Fee Pressure? Evidence of Increased Focus on Nonaudit Services and their Impact on Audit Quality. Contemporary Accounting Research, 36(2), 999-1027.

Beattie, V. (2014). Accounting narratives and the narrative turn in accounting research: issues, theory, methodology, methods and a research framework. The British Accounting Review, 46(2), 111-134.

Beattie, V., \& Fearnley, S. (2002). Auditor independence and non-audit services: a literature review. The Institute of Chartered Accountants in England and Wales, London.

Beattie, V., McInnes, B., \& Fearnley, S. (2004). A methodology for analysing and evaluating narratives in annual reports: A comprehensive descriptive profile and metrics for disclosure quality attributes. Accounting Forum, 28(3), 205-239. 
Beattie, V., \& Smith, J. (2012). Evaluating disclosure theory using the views of UK finance directors in the intellectual capital context. Accounting and Business Research, 42(5), 471-494.

Beck, A.C., Campbell, D., \& Shrives, P.J. (2010). Content analysis in environmental reporting research: enrichment and rehearsal of the method in a British-German context. The British Accounting Review, 42, 207-222.

Becker, C., DeFond, M.L., Jiambalvo, J., \& Subramanyam, K.R. (1998). The effect of audit quality on earnings management. Contemporary Accounting Research, 15, 1-24.

Bédard, J., \& Chi, M.T.H. (1993). Expertise in auditing. Auditing: A Journal of Practice \& Theory, 12, 21-45.

Beekes, W., \& Brown, P. (2006). Do better-governed Australian firms make more informative disclosures? Journal of Business Finance and Accounting, 33(3-4), 422450.

Bell, T.B., Doogar, R., \& Solomon, I. (2008). Audit labor usage and fees under business risk auditing. Journal of Accounting Research, 46(4), 729-760.

Bell, T.B., Marris, F.O., Solomon, I., \& Thomas, H. (1997). Auditing organizations through a strategic systems lens. Montvale, NJ: KPMG LLP.

Bell, T.B., Landsman, W.R., \& Shackelford, D.A. (2001). Auditors' perceived business risk and audit fees: Analysis and evidence. Journal of Accounting Research, 39(1), 35-43.

Bengtsson, M. (2016). How to plan and perform a qualitative study using content analysis. International Journal of Nursing Practice. Research and Education, 2, 8-14.

Bergh, A., Erlingsson, G., Gustafsson, A., \& Wittberg, E. (2019). Municipally Owned Enterprises as Danger Zones for Corruption? How Politicians Having Feet in Two Camps May Undermine Conditions for Accountability. Public Integrity, 21(3), 320352.

Beyer, A., Cohen, D.A., Lys, T.Z., \& Walther, B.R. (2010). The financial reporting environment: review of the recent literature. Journal of Accounting and Economics, 50(1-2), 296-343. 
Bierstaker, J., \& Wright, A. (2001). The effects of fee pressure and partner pressure on audit planning decisions. Advances in Accounting, 18, 25-46.

Bigus, J., \& Zimmermann, R-C. (2008). Non-audit fees, market leaders and concentration in the German audit market: A descriptive analysis. International Journal of Auditing, 12(3), 159-179.

Billis, D. (2010). Towards a theory of hybrid organizations. In D. Billis (Ed.), Hybrid organizations and the third sector: challenges for practice, theory and policy. Basingstoke, Hampshire, UK: Palgrave Macmillan.

Birnberg, J.G., Shields, M.D., \& Young, S.M. (1990). The case for multiple methods in empirical management accounting research (With an Illustration from Budget Setting). Journal of Management Accounting Research, 2, 33-66.

Boesso, G., \& Kumar, K. (2007). Drivers of corporate voluntary disclosure; a framework and empirical evidence from Italy and the United States. Accounting, Auditing and Accountability Journal, 20(2), 269-296.

Boskou, G., Kirkos, E., \& Spathis, C. (2019). Classifying internal audit quality using textual analysis: the case of auditor selection. Managerial Auditing Journal, 34(8), 924-950.

Botosan, C. (1997). Disclosure level on the cost of equity capital. The Accounting Review, 72(3), 323-349.

Boverket. (2017). Allmännyttiga kommunala bostadsaktiebolag-utvärdering av tillämpning av gällande lagstiftning, 2017, Boverket.

Brandsen, T., \& Karré, P.M. (2011). Hybrid organizations: no cause for concern? International Journal of Public Administration, 34(13), 827-836.

Braun, V., \& Clarke, V. (2006). Using thematic analysis in psychology. Qualitative Research in Psychology, 3(2), 77-101.

Broberg, P. (2013). The auditor at work: A study of auditor practice in Big 4 audit firms. Doctoral Dissertation, Lund University, School of Economics and Management.

Brumfield, C.A., Elliott, R.K., \& Jacobson, P.D. (1983). Business risk and the audit process. Journal of Accountancy, 155(4), 60-68. 
Bruton, G.D., Peng, M.W., Ahlstrom, D., Stan, C., \& Xu, K. (2015). State-owned enterprises around the world as hybrid organizations. Academy of Management Perspectives, 29(1), 92-114.

Bryman, A., \& Cramer, D. (2005). Quantitative data analysis with SPSS 12 and 13: A guide for social scientists. London: Routledge.

Caneghem, T.V. (2010). Audit pricing and the Big4 fee premium: evidence from Belgium. Managerial Auditing Journal, 25(2), 122-139.

Carson, E. (2009). Industry specialization by global audit firm networks. The Accounting Review, 84(2), 355-382.

Carson, E. (2014). Globalization of auditing. Ch. 3. In Hay, D., Knechel, R.W., \& Willekens, M. (Eds.), Routledge Companion to Auditing (pp.23-32). Routledge: Abingdon and New York.

Casterella, J.R., Francis, J.R., Lewis, B.L., \& Walker, P.L. (2004). Auditor industry specialization, client bargaining power and audit pricing. Auditing: A Journal of Practice \& Theory, 23(1), 123-140.

Causholli, M., Martinis., M.D., Hay, D., \& Knechel, W.R. (2011). Audit markets, fees and production: Towards an integrated view of empirical audit research. Journal of Accounting Literature, 29, 167-215.

Chan, P., Ezzamel, M., \& Gwilliam, D. (1993). Determinants of audit fees for quoted UK companies. Journal of Business Finance \& Accounting, 20(6), 765-786.

Chaney, P.K., Jeter, D.C., \& Shivakumar, L. (2004). Self-selection of auditors and audit pricing in private firms. Accounting Review, 79 (1), 51-72.

Chen, L., Krishnan, G.V., \& Yu, W. (2018). The relation between audit fee cuts during the global financial crisis and earnings quality and audit quality. Advances in Accounting, $43,14-31$.

Christensen, T., \& Lægreid, P. (2011). Complexity and Hybrid Public Administration Theoretical and Empirical Challenges. Public Organization Review, 11(4), 407-23. 
Christensen, B.E., Omer, T.C., Sharp, N.Y., \& Shelley, M.K. (2014). Pork bellies and public company audits: have audits once again become just another commodity? Working paper, Texas A\&M University, College Station, TX

Cobbin, P. E. (2002). International dimensions of the audit fee determinants literature. International Journal of Auditing, 6, 53-77.

Cohen, S., \& Leventis, S. (2013). An empirical investigation of audit pricing in the public sector: The case of Greek LGOs. Financial Accountability \& Management, 29(1), 7498.

Collin, S.-O., \& Tagesson, T. (2010). Governance strategies in local government: a study of governance of municipal corporations in a Swedish municipality. International Journal of Public Policy, 5(4), 373-389.

Collin, S.-O., Haraldsson, M., Tagesson, T., \& Blank, V. (2017). Explaining municipal audit costs in Sweden: Reconsidering the political environment, the municipal organisation and the audit market. Financial Accountability \& Management, 33, 391405.

Connelly, B.L., Certo, S.T., Ireland, R.D., \& Reutzel, C.R. (2011). Signaling theory: A review and assessment. Journal of Management, 37(1), 39-67.

Cooper, D.J., \& Morgan, W. (2008). Case study research in accounting. Accounting Horizons, 22(2), 159-178.

Courtis, J.K. (2004). Corporate report obfuscation: artefact or phenomenon? British Accounting Review, 36(3), 291-312.

Craswell, A.T., Francis, J.R., \& Taylor, S.L. (1995). Auditor brand name reputations and industry specializations. Journal of Accounting and Economics, 20(3), 297-322.

Craswell, A.T., \& Francis, J.R. (1999). Pricing initial audit engagements: A test of competing theories. The Accounting Review, 74(2), 201-216.

Creswell, J.W. (1994). Research design: Qualitative \& quantitative approaches. Thousand Oaks, CA, US: Sage Publications, Inc. 
Creswell, J.W. (2007). Qualitative inquiry and research design: choosing among five approaches. (2nd ed.) Thousand Oaks: Sage Publications.

Creswell, J.W. (2012). Qualitative inquiry \& research design: Choosing among five approaches (4th ed.). Thousand Oaks, CA: Sage.

Creswell, J.W. (2009). Research design: Qualitative, quantitative, and mixed methods approaches (3rd ed.). Thousand Oaks, CA, US: Sage Publications, Inc.

Creswell, J.W. (2014). Research design: Qualitative, quantitative, and mixed methods approaches (4th ed.). Thousand Oaks, CA, US: Sage Publications, Inc.

Creswell, J.W., \& Plano Clark, V. (2007). Designing and conducting mixed methods research. Thousand Oaks, CA: SAGE Publications.

Datar, S.M., Feltham, G.A., \& Hughes, J.S. (1991). The role of audits and audit quality in valuing new issues. Journal of Accounting and Economics, 14, 3-49.

Davis, L.R., Ricchiute, D.N., \& Trompeter, G. (1993). Audit Efforts, Audit Fess, and the provision of Non-audit Services to Audit Clients. The Accounting Review, 68(1), 135150.

DeAngelo, L.E. (1981a). Auditor independence, "low balling", and disclosure regulation. Journal of Accounting and Economics. 3(2), 113-127.

DeAngelo, L.E. (1981b). Auditor size and audit quality. Journal of Accounting \& Economics, 3, 183-200.

DeFond, M. (1992). The association between changes in client firm agency costs and auditor switching. Auditing: A Journal of Practice \& Theory, 11(1), 16-31.

DeFond, M., \& Jiambalvo, J. (1994). Debt covenant violation and manipulation of accruals. Journal of Accounting and Economics, 17(1), 145-176.

DeFond, M., Raghunandan, K., \& Subramanyam, K.R. (2002). Do Non-Audit Service Fees Impair Auditor Independence? Evidence from Going Concern Audit Opinions. Journal of Accounting Research, 40(4), 1247-1274. 
DeFond, M., \& Zhang, J. (2014). A review of archival auditing research. Journal of Accounting and Economics, 58(2), 275-326.

Denscombe, M. (2010). The Good Research Guide for Small Scale Research Projects (4th ed.). Buckingham: Open University Press.

Diamond, D., \& Verrecchia, R. (1991). Disclosure, liquidity and the cost of capital. The Journal of Finance, 46(4), 1325-1359.

Diouf, D., \& Boiral, O. (2017). The quality of sustainability reports and impression management: A stakeholder perspective. Accounting, Auditing and Accountability Journal, 30(3), 643-667.

Doherty, B., Haugh, H., \& Lyon, F. (2014). Social enterprises as hybrid organizations: a review and research agenda. International Journal of Management Reviews, 16, 417436.

Downey, D.H. (2018). An exploration of offshoring in audit practice and the potential consequences of associated work "redesign" on auditor performance. Auditing: A Journal of Practice \& Theory, 37(2), 197-223.

Ebrahim, A., Battilana, J., \& Mair, J. (2014). The governance of social enterprises: Mission drift and accountability challenges in hybrid organizations. Research in Organizational Behavior, 34, 81-100.

Eilifsen, A., Messier, W., Glover, S., \& Prawitt, D. (2014). Auditing and assurance services - international edition. McGraw Hill Higher Education.

Eisenhardt, K.M., \& Graebner, M.E. (2007). Theory building from cases: Opportunities and challenges. Academy of Management Journal, 50(1), 25-32.

Elo, S., \& Kyngäs, H. (2008). The qualitative content analysis process. Journal of Advanced Nursing, 62, 107-115.

Endenich, C., \& Trapp, R. (2018). Signaling Effects of Scholarly Profiles - The Editorial Teams of North American Accounting Association Journals. Critical Perspectives on Accounting, 51, 4-23. 
Erickson, M., Mayhew, B.W., \& Felix, W. L. (2000). 'Why do audit fail?' Evidence from Lincoln savings and loan. Journal of Accounting Research, 38(1), 165-194.

Erlingsson, G.Ó., Bergh, A., \& Sjölin, M. (2008). Public corruption in Swedish municipalities - Trouble looming on the horizon. Local Government Studies, 34(5), 595-608.

Erlingsson, G.Ó., Fogelgren, M., Olsson, F., Thomasson, A., \& Öhrvall, R. (2014). Hur styrs och granskas kommunala bolag? Erfarenheter och lärdomar från Norrköpings kommun. Centrum för Kommunstrategiska studier, Linköpings universitet, Rapport 2014:6.

Erlingsson, G.Ó., Fogelgren, M., Olsson, F., Thomasson, A., \& Öhrvall, R. (2015). Att bolagisera kommunal verksamhet. Implikationer för granskning, ansvarutkrävande och demokrati? Statsvetenskaplig tidskrift, 117(4), 555-585.

Eshleman, J.D., \& Lawson, B.P. (2017). Audit market structure and audit pricing. Accounting Horizons, 31(1), 57-81.

Ettredge, M., Fuerherm, E.E., \& Li, C. (2014). Fee pressure and audit quality. Accounting, Organizations and Society, 39(4), 247-263.

Ettredge, M., Fuerherm, E.E., Guo, F., \& Li, C. (2017). Client pressure and auditor independence: Evidence from the "Great Recession" of 2007-2009. Journal of Accounting and Public Policy, 36, 262-283.

Ettredge, M., \& Greenberg, R. (1990). Determinants of Fee Cutting on Initial Audit Engagements. Journal of Accounting Research, 28(1), 198-210.

Ezzamel, M., Gwilliam, D.R., \& Holland, K.M. (1996). Some Empirical Evidence from Publicly Quoted UK Companies on the Relationship Between the Pricing of Audit and Non-audit Services. Accounting \& Business Research, 27(1), 3-16.

Ezzamel, M., Gwilliam, D.R., \& Holland, K.M. (2002). The relationship between categories of non-audit services and audit fees: Evidence from U.K. companies. International Journal of Auditing, 6(1), 13-35. 
Felix, W.L., Gramling, A.A., \& Maletta, M.J. (2001). The contribution of internal audit as a determinant of external audit fees and factors influencing this contribution. Journal of Accounting Research, 39(3), 513-534.

Firth, M. (1997). The provision of non-audit services and the pricing of audit fees. Journal of Business Finance and Accounting, 24(3), 511-525.

Flint, D. (1988). Philosophy and principles of auditing. An introduction. London: Macmillan Education.

Francis, J.R., \& Wilson, E.R. (1988). A Joint Test of theories Relating to Agency Costs and Auditor Differentiation. The Accounting Review, 63(4), 663-682.

Francis, J.R., Reichelt, K., \& Wang, D. (2005). The pricing of national and city-specific reputations for industry expertise in the US audit market. The Accounting Review, 80(1), 113-136.

Francis, J.R. (2011). A Framework for Understanding and Researching Audit Quality. Auditing: A Journal of Practice \& Theory, 30(2), 125-152.

Francis, J.R., Michas, P., \& Seavey, S. (2013). Does audit market concentration harm the quality of audited earnings? Evidence from audit markets in 42 countries. Contemporary Accounting Research, 30(1), 325-355.

Frostenson, M., \& Helin, S. (2017), Ideas in conflict: a case study on tensions in the process of preparing sustainability reports. Sustainability Accounting, Management and Policy Journal, 8(2), 166-190.

Fung, S.Y.K., Gul, F.A., \& Krishnan, J. (2012). City-Level Auditor Industry Specialization, Economies of Scale, and Audit Pricing. The Accounting review, 87(4), 1281-1307.

Gabrielsson, J. (2012). Corporate governance and initial public offerings in Sweden. In A. Zattoni, \& W. Judge (Eds.), Corporate governance and initial public offerings: An international perspective (pp. 422-448). New York, NY: Cambridge University Press.

Gall, J.G., Gall, M.D., \& Borg, W.R. (1999). Applying educational research a practical guide (4th ed.). New York, NY: Longman. 
Gendron, Y., Bédard, J., \& Gosselin., M. (2004). Getting Inside the Black Box: A Field Study of Practices in "Effective" Audit Committees. Auditing: A Journal of Practice \& Theory, 23(1), 153-171.

Gerrard, I., Houghton, K., \& Woodliff, D. (1994). Audit fees: the effects of auditee, auditor and industry differences. Managerial Auditing Journal, 9, 3-11.

Gibbins, M., Richardson, A., \& Waterhouse, J. (1990). The management of corporate financial disclosure: opportunism, ritualism, policies, and processes. Journal of Accounting Research, 28, 121-143.

Gist, W. (1992). Explaining variability in external audit fees. Accounting and Business Research, 23(89), 74-84.

Godfrey, J., Mather, P., \& Ramsay, A. (2003). Earnings and impression management in financial reports: the case of CEO changes. Abacus, 39(1), 95-123.

Goertz, G., \& Mahoney, J. (2012). A Tale of Two Cultures: Qualitative and Quantitative Research in the Social Sciences. Princeton, NJ: Princeton University Press.

Gonthier-Besacier, N., \& Schatt, A. (2007). Determinants of audit fees for French quoted firms. Managerial Auditing Journal, 22(2), 139-160.

Goodwin, J., \& Wu, D. (2014). Is the effect of industry expertise on audit pricing an officelevel or a partner-level phenomenon? Review of Accounting Studies, 19(4), 1532-1578.

Goodwin-Stewart, J., \& Kent, P. (2006). Relation between external audit fees, audit committee characteristics, and internal audit. Accounting and Finance, 46, 387-404.

Gramling, A., \& Stone, D. (2001). Audit firm industry expertise: A review and synthesis of archival literature. Journal of Accounting Litterature, 20, 1-27.

Gramling, A., Maletta, M.J., Schneider, A., \& Church, B.K. (2004). The role of the internal audit function in corporate governance: A synthesis of the extant internal auditing literature and directions for future research. Journal of Accounting Literature, 23, 194244. 
Griffin, P.A., Lont, D.H., \& Sun, Y. (2009). Governance regulatory changes, International Financial Reporting Standards adoption, and New Zealand audit and non-audit fees: empirical evidence. Accounting and Finance, 49(4), 697-724.

Gros, M., Koch, S., \& Wallek, C.J. (2017). Internal audit function quality and financial reporting: Results of a survey on German listed companies. Journal of Management and Governance, 21(2), 291-329.

Grossi, G., \& Reichard, C. (2008). Municipal corporatization in Germany and Italy. Public Management Review, 10(5), 597-617.

Grossi, G., \& Thomasson, A. (2015). Bridging the accountability gap in hybrid organizations: The case of Copenhagen Malmö Port. International Review of Administrative Science, 81(3), 604-620.

Grossi, G., Reichard, C., Thomasson, A., \& Vakkuri, J. (2017). Editorial. Public Money \& Management, 37(6), 379-386.

Gujarati, D.N. (2004). Basic Econometrics. 4th Edition, McGraw-Hill Companies.

Gul, F.A., \& Tsui, J. S. L. (1998). A test of the free cash flow and debt monitoring hypotheses: Evidence from auditing pricing. Journal of Accounting and Economics, 2(24), 219-237.

Gul, F.A. (2006). Auditors' response to political connections and cronyism in Malaysia. Journal of Accounting Research, 44(5), 931-963.

Gul, F.A., Wu, D., \& Yang, Z. (2013). Do Individual Auditors Affect Audit Quality: Evidence From Archival Data. The Accounting Review, 88(6), 1993-2023.

Graneheim, U.H., \& Lundman, B. (2004). Qualitative content analysis in nursing research: conceps, procedures and measures to achieve trustworthiness. Nurse Education Today, $24,105-112$.

Greene, J.C., Caracelli, V.J., \& Graham, W.F. (1989). Toward a conceptual framework for mixed-method evaluation designs. Educational Evaluation and Policy Analysis, 11, 255-274. 
Hair, J.F., Black, W.C., Babin, B.J., \& Anderson, R.E. (2014). Multivariate Data Analysis (7th ed.). US: Pearson.

Hay, D., Knechel, W.R., \& Wong, N. (2006). Audit fees: a meta-analysis of the effect of supply and demand attributes. Contemporary Accounting Research, 23(1) 141-191.

Hay, D., Knechel, W.R., \& Li, V. (2006). Non-audit services and auditor independence: New Zealand evidence. Journal of Business Finance \& Accounting, 33(5-6), 715-734.

Hay, D., Knechel, W.R., \& Ling, H. (2008). Evidence on the impact of internal control and corporate governance on audit fees. International Journal of Auditing, 12(1), 9-24.

Hay, D. (2013). Further evidence from meta-analysis of audit fee research. International Journal of Auditing, 17(2), 162-176.

Hay, D., Knechel, W.R., \& Willekens, M. (2014). Introduction: The function of auditing. Ch. 1. In Hay, D., Knechel, R.W., \& Willekens, M. (Eds.), Routledge Companion to Auditing (pp.1-10). Routledge: Abingdon and New York.

Healy, P., \& Palepu, K. (2001). Information asymmetry, corporate disclosure, and the capital markets: a review of the empirical disclosure literature. Journal of Accounting and Economics, 31, 405-440.

Hofer, C. W. (1980). Turnaround Strategies. Journal of Business Strategy. 1, 19-31.

Holt, T. P., \& DeZoort, T. (2009). The effects of internal audit report disclosure on investor confidence and investment decisions. International Journal of Auditing, 13(1), 61-77.

Holt, A. (2010). Using the telephone for narrative interviewing: a research note. Qualitative Research, 10(1), 113-121.

Holland, J., \& Stoner, G. (1996). Dissemination of price-sensitive information and management of voluntary corporate disclosure. Accounting and Business Research, 26, 295-313.

Holland, J. (2005). A grounded theory of corporate disclosure. Accounting and Business research, 35, 249-267. 
Holm, C., \& Thinggaard, F. (2014). Leaving a joint audit system: conditional fee reductions. Managerial Auditing Journal, 29(2), 131-152.

Hood, C. (1991). A public management for All seasons? Public Administration, 69, 3-19.

Hood, C. (1995). The "New Public Management" in the 1980s: variations on a theme. Accounting, Organization and Society, 20(2/3), 93-109.

Hooghiemstra, R. (2000). Corporate communication and impression management - new perspectives why companies engage in corporate social reporting. Journal of Business Ethics, 27, 55-68.

Hope, O., \& Langli, J. (2010). Auditor independence in a private firm and low litigation risk setting. The Accounting Review, 85(2), 573-605.

Houston, R.W. (1999). The effects of fee pressure and client risk on audit seniors' time budget decisions. Auditing: A Journal of Practice and Theory, 18(2), 70-86.

Hoque, Z., Covaleski, M.A., \& Gooneratne, T.N. (2013). Theoretical triangulation and pluralism in research methods in organizational and accounting research. Accounting, Auditing \& Accountability Journal, 26(7) 1170-1198.

Humphrey, C. (2008). Auditing research: A review across the disciplinary divide. Accounting, Auditing \& Accountability Journal, 21(2), 170-203.

Hsiao, C. (2007). Panel data analysis_-Advantages and challenges. Test, 16, 1-22.

Hsieh, H.F., \& Shannon S. (2005). Three approaches to qualitative content analysis. Qualitative Health Research, 15, 1277-1288.

International Ethics Standards Board for Accountants (IESBA). (2016). Ethical Considerations Relating to Audit Fee Setting in the Context of Downward Fee Pressure. New York, NY: IESBA.

International Auditing and Assurance Standards Board. (2013). International Standard on Auditing (ISA) No. 315. Identifying and assessing the risks of material misstatement through understanding the entity and its environment. New York: IAASB. 
International Auditing and Assurance Standards Board. (2009). International Standard on Auditing (ISA) No. 330. The auditor's responses to assessed risks. New York: IAASB. Ireland, J.C., \& Lennox, C.S. (2002). The Large Audit Firm Fee Premium: A Case of Selectivity Bias? Journal of Accounting, Auditing \& Finance, 17(1), 73-91.

Ittonen, K., \& Peni, E. (2012). Auditor's gender and audit fees. International Journal of Auditing, 16(1), 1-18.

Ivankova, N.V., Creswell, J.W., \& Stick, S.L. (2006). Using Mixed-Methods Sequential Explanatory Design: From Theory to Practice. Field Methods, 18(1), 3-20.

Jaggi, B., \& Tsui, J. (1999). Determinants of audit report lag: further evidence from Hong Kong. Accounting and Business Research, 30(1), 17-28.

Jensen, M., \& Meckling, W. (1976). Theory of the firm: Managerial behavior, agency costs, and ownership structure. Journal of Financial Economics, 3, 305-350.

Johnsen, Å., Meklin, P., Oulasvirta, L., \& Vakkuri, J. (2004). Governance structures and contracting out municipal auditing in Finland and Norway. Financial Accountability and Management, 20(4), 445-477.

Johnson, R.B., \& Onwuegbuzie, A.J. (2004). Mixed Methods Research: A Research Paradigm Whose Time Has Come. Educational Researcher, 33(7), 14-26.

Johnson, R.B., Onwuegbuzie, A.J., \& Turner, L.A. (2007). Toward a Definition of Mixed Methods Research. Journal of Mixed Methods Research, 1(2), 112-133.

Johnstone, K. (2000). Client-acceptance decisions: Simultaneous effects of client business risk, audit risk, auditor business risk, and risk adaptation. Auditing: A Journal of Practice \& Theory, 19(1), 1-25.

Jones, M.J., \& Shoemaker, P.A. (1994). Accounting narratives: A review of empirical studies of content and readability. Journal of Accounting Literature, 13, 142-185.

Kallapur, S., Sankaraguruswamy, S., \& Zang, Y. (2010). Audit Market Concentration and Audit Quality. Working paper, Indian school of business, National University of Singapore, Singapore Management University. 
Kankaanpää, J., Oulasvirta, L., \& Wacker, J. (2014). Steering and monitoring model of state-owned enterprises. International Journal of Public Administration, 37(7), 409423.

Kickert, W.J.M. (2001). Public management of hybrid organizations: Governance of quasiautonomous executive agencies. International Public Management Journal, 4(2), 135150.

Kim, H., \& Fukukawa, H. (2013). Japan's Big 3 firms' response to clients' business risk: Greater audit effort or higher audit fees? International Journal of Auditing, 17(2), 190212.

Knechel, W.R., \& Payne, J.L. (2001). Additional evidence on audit report lag. Auditing: A Journal of Practice \& Theory, 20(1), 137-146.

Knechel, W.R., Niemi, L., \& Sundgren, S. (2008). Determinants of auditor choice: Evidence from a small client market. International Journal of Auditing, 12(1), 65-88.

Knechel, W.R., Krishnan, G.V., Pevzner, M., Shefchik, L.B., \& Velury, U.K. (2013). Audit quality: Insights from the academic literature. Auditing: A Journal of Practice \& Theory, 32(Supplement 1), 385-421.

Knechel, W.R. (2013). Do audit standards matter? Current Issues in Auditing, 7(2), A1A16.

Knechel, W.R., \& Shefchik, L.B. (2014). Audit quality. Ch. 11. In Hay, D., Knechel, R.W., \& Willekens, M. (Eds.), Routledge Companion to Auditing (pp.130-147). Routledge: Abingdon and New York.

Knutsson, H., \& Thomasson, A. (2017). Exploring organisational hybridity from a learning Perspective. Qualitative Research in Accounting \& Management, 14(4), 430-447.

Krippendorff, K. (2013). Content Analysis: An Introduction to its Methodology, 3rd ed, Sage, Thousand Oaks, CA.

Krippendorff, K. (2018). Content analysis: An introduction to its methodology (4th ed.). Thousand Oaks, CA: Sage Publications. 
Krishnan, G., \& Zhang, Y. (2014). Is there a relation between audit fee cuts during the global financial crisis and banks' financial reporting quality? Journal of Accounting and Public Policy, 33(3), 279-300.

Köhler, A.G., \& Ratzinger-Sakel, N.V.S. (2012). Audit and non-audit fees in Germany The impact of audit market characteristics. Schmalenbach Business Review, Vol. 64 No. 4 pp. 281-307.

Langli, J.C., \& Svanström, T. (2014). Audits of private companies. Ch. 12. In Hay, D., Knechel, R.W., \& Willekens, M. (Eds.), Routledge Companion to Auditing (pp.148158). Routledge: Abingdon and New York.

Langli, J.C., \& Willekens, M. (2018). The Economic of Auditor Regulation. Ch. 10. In Sasson, A. (Ed.), At the forefront, looking ahead, Research-based answers to contemporary uncertainties of management (pp.159-176). Universitetsforlaget.

Lekvall, P. (Ed.) (2014). The Nordic corporate governance model. Stockholm: SNS Förlag.

Leung, S., Parker, L., \& Curtis, J. (2015). Impression management through minimal narrative disclosure in annual reports. The British Accounting Review, 47(3), 275-289.

Lennox, C.S. (1999). Audit quality and auditor size: an evaluation of reputation and deep pocket hypotheses. Journal of Business Finance \& Accounting, 26(7), 779-805.

Lenz, H., \& James, M.L. (2007). International audit firms as strategic networks-The evolution of global professional service firms. In Economics and Management of Networks, (Eds.), G. Cliquet, M. Tuunanen, G. Hendrikese, and J. Windsperger, 367392. Heidelberg, Germany: Physica-Verlag.

Leuz, C., \& Verrecchia, R. (2005). Firms capital allocation choices, information quality, and the cost of capital, working paper, The Wharton School, University of Pennsylvania.

Libby, R., \& Rennekamp, K. (2012). Self-serving attribution bias, overconfidence, and the issuance of management forecasts. Journal of Accounting Research, 50(1), 197-231.

Lincoln, Y.S., \& Guba, E.G. (1985). Naturalistic Inquiry. Beverly Hills, CA Sage Publications, Inc. 
Lindqvist, K. (2013). Hybrid governance: The case of household solid waste management in Sweden. Public Organizational Review, 13, 143-154.

Margheim, L., \& Kelly, T. (1992). The perceived effects of fixed fee audit billing arrangements. Accounting Horizons, 6(4), 62-75.

Maxwell, J.A. (1992). Understanding and validity in qualitative research. Harvard Educational Review, 62(3), 279-300.

Mayhew, B.W., \& Wilkins, M.S. (2003). Audit firm industry specialization as a differentiation strategy: Evidence from fees charged to firms going public. Auditing: A Journal of Practice \& Theory, 22(2), 33-52.

Mayorga, D. (2013). Managing continuous disclosure: Australian evidence, Accounting, Auditing \& Accountability Journal, 26(7), 1135-1169.

Mayring, P. (2000). Qualitative content analysis. Forum: Qualitative Social Research, 1(2): Art. 20. Retrieved from http://www.qualitativeresearch.net/index.php/fqs/article/viewArticle /1089/2385 (accessed April 17, 2018).

McMillian, S.J. (2000). The microscope and the moving target: The challenge of applying content analysis to the world wide web. Journalism \& Mass Communication Quarterly, 77(1), 80-98.

Meek, G., Roberts, C., \& Gray, S. (1995). Factors influencing voluntary annual report disclosures by U.S., U.K. and continental European multinational corporations. Journal of Business Studies, 21(3), 555-572.

Merkl-Davies, D.M., \& Brennan, N.M. (2007). Discretionary disclosure strategies in corporate narratives: incremental information or impression management? Research Repository, University College Dublin, 1-91.

Merkl-Davies, D.M., \& Brennan, N.M. (2011). A conceptual framework of impression management: new insights from psychology, sociology and critical perspectives. Accounting and Business Research, 41(5), 415-437.

Merriam, S.B. (2009). Qualitative research: A guide to design and implementation. San Francisco, CA: John Wiley \& Sons. 
Meuwissen, R. (2014). The auditing profession. Ch. 2. In Hay, D., Knechel, R.W., \& Willekens, M. (Eds.), Routledge Companion to Auditing (pp.13-22). Routledge: Abingdon and New York.

Modell, S. (2010). Bridging the paradigm divide in management accounting research: The role of mixed methods approaches. Management Accounting Research, 21, 124-129.

Morrow, J.L., Johnson, R.A., \& Busenitz, L.W. (2004). The effects of cost and asset retrenchment on firm performance: The overlooked role of a firm's competitive environment. Journal of Management, 30, 271-283.

Neu, D., Warsame, H., \& Pedwell, K. (1998). Managing public impressions: environmental disclosures in annual reports. Accounting, Organizations and Society, 23(3), 265-82.

Neuendorf, K. (2002). The content analysis guide book, Thousand Oaks, California. Sage Publications Inc.

$\mathrm{Ng}$, D. (1978). An information economics analysis of financial reporting and external auditing. The Accounting Review, 53(4), 910-920.

Niemi, L. (2002). Do firms pay for audit risk? Evidence on risk premiums in audit fees after direct control for audit effort. International Journal of Auditing, 6(1), 37-51.

Niemi, L. (2003). Essays on audit pricing. Helsinki school of economics, HeSE, 2003.

Niemi, L. (2005). Audit effort and fees under concentrated client ownership: Evidence from four international audit firms. International journal of Accounting, 40(4), 303-323.

Niemi, L., Knechel, W.R., Ojala, H., \& Collis, J. (2018). Responsiveness of Auditors to the Audit Risk Standards: Unique Evidence from Big 4 Audit Firms. Accounting in Europe, $15(1), 33-54$.

Nikkinen, J., \& Sahlström, P. (2003). Do auditors assess the systematic market risk in their audit pricing decisions? International evidence. Advances in Accounting, 20, 233-244.

Nikkinen, J., \& Sahlström, P. (2004). Does agency theory provide a general framework for audit pricing? International Journal of Auditing, 8, 253-262. 
Niskanen, M., Karjalainen, J., \& Niskanen, J. (2011). Demand for audit quality in private firms: evidence on ownership effects. International Journal of Auditing, 15 (1), 43-65.

Numan, W., \& Willekens, M. (2012). An empirical test of spatial competition in the audit market. Journal of Accounting and Economics, 53(1-2), 450-465.

O’Dwyer, B. (2002). Managerial perceptions of corporate social disclosure: an Irish story, Accounting, Auditing \& Accountability Journal, 15(3), 406-436.

O’Keefe, T.B., Simunic, D.A., \& Stein, M. (1994). The production of audit services: Evidence from a major public accounting firm. Journal of Accounting Research, 32(2), pp. 241-261.

Olusegun, A.S. (2002). Selecting a quantitative or qualitative research methodology: An experience. Educational Research Quarterly, 26(1), 3-10.

O'Sullivan, N. (2000). The impact of board composition and ownership on audit quality: Evidence from large UK companies. British Accounting Review, 32, 397-414.

Oxera Consulting. (2006). Competition and choice in the U.K. audit market: Prepared for Department of Trade and Industry and Financial Reporting Council. Oxford, UK: Oxera Consulting.https://www.oxera.com/wp-content/uploads/media/Oxera/downloads/reports/Competition-and-choice-in-the-UK-audit-market\%E2\%80\%94executivesummary_1.pdf (Accessed: May 28, 2019).

Oxera Consulting. (2007). Ownership Rules of Audit Firms and Their Consequences for Audit Market Concentration. Oxford, UK: Oxera Consulting. https://www.oxera.com/wp-content/uploads/2018/03/Ownership-rules-of-auditfirms.pdf (Accessed: May 28, 2019).

Pache, A.-C., \& Santos, F. (2013). Inside the hybrid organization: Selective coupling as a response to competing institutional logics. Academy of Management Journal, 56, 9721001.

Palmrose, Z-V. (1986). Audit fees and auditor size: Further evidence. Journal of Accounting Research, 24(1), 97-110. 
Parker, L.D. (2003). Qualitative research in accounting and management: the emerging agenda. Journal of Accounting and Finance (South Korea), 2, 15-30.

Patton, M.Q. (2002). Qualitative research \& evaluation methods. Thousand Oaks, CA: Sage Publications.

Pearson, T., \& Trompeter, G. (1994). Competition in the market for audit services: The effect of supplier concentration on audit fees. Contemporary Accounting Research, 11(1), 115-135.

Polkinghorne, D.E. (2005). Language and meaning: Data collection in qualitative research. Journal of Counseling Psychology, 52(2), 137-145.

Power, M. (1997). The audit society: Rituals of verification. Oxford: Oxford University Press.

Power, M., \& Gendron, Y. (2015). Qualitative Research in Auditing: A Methodological Roadmap. Auditing: A Journal of Practice \& Theory, 34(2), 147-165.

Pratt, J., \& Stice, J.D. (1994). The effects of client characteristics on auditor litigation risk judgments, required audit evidence, and recommended audit fees. The Accounting Review, 69(4), 639-656.

Prawitt, D., Sharp, N., \& Wood, D. (2011). Reconciling archival and experimental research: Does internal audit contribution affect the external audit fee? Behavioral Research in Accounting, 23(2), 187-206.

Public Company Accounting Oversight Board (PCAOB). (2010). Report on observations of PCAOB inspectors related to audit risk areas affected by the economic crisis. Release No. 2010-006.

Qu, S., and Dumay, J. (2011). The qualitative research interview. Qualitative Research in Accounting \& Management, 8(3), 238-264.

Redmayne, N.B., Bradbury, M.E., \& Cahan, S.F. (2010). The effect of political visibility on audit effort and audit pricing. Accounting and Finance, 50, 921-939.

Reichelt, K., \& Wang, D. (2010). National and office-specific measures of auditor industry expertise and effects on audit quality. Journal of Accounting Research, 48(3), 647-686. 
Roberts, R.W. (2018). We can do so much better: Reflections on reading Signaling Effects of Scholarly Profiles - The Editorial Teams of North American Accounting Association Journals. Critical Perspectives on accounting, 51, 70-77.

Rosner, R.L. (2003). Earnings Manipulation in Faling Firms. Contemporary Accounting Research, 20(2), 361-408.

Roychowdhury, S. (2006). Earnings management through real activities manipulation. Journal of Accounting and Economics, 42(3), 335-370.

Rutherford, B.A. (2003). Obfuscation, Textual Complexity and the Role of Regulated Narrative Accounting Disclosure in Corporate Governance. Journal of Management and Governance, 7(2), 187-210.

Rutherford, B.A. (2005). Genre analysis of corporate annual report narratives: A corpus linguistics based approach. Journal of Business Communication, 42(4), 324-348.

Rynes, S., \& Gephart, R. (2004). From the editors: Qualitative research and the academy of management journal. Academy of Management Journal, 47, 454-462.

SALAR. (2013). Lekmannarevision i praktiken - Demokratisk granskning av kommunala bolag, 2013, Swedish Association of Local Authorities and Regions.

Saldaña, J. (2009). The coding manual for qualitative researchers, Thousand Oaks. California: Sage Publications Inc.

Sands, V. (2006). The right to know and obligation to provide: Public-private partnerships, public knowledge, public accountability, public disenfranchisement and prison cases. UNSW Law Journal, 29(3), 334-341.

Schelleman, C., \& Knechel, W.R. (2010). Short-term accruals and the pricing and production of audit services. Auditing: A Journal of Practice and Theory, 29(1), 221250.

Seetharaman, A., Gul, F.A., \& Lynn, S.G. (2002). Litigation risk and audit fees: evidence from UK firms cross-listed on US market. Journal of Accounting and Economics, 33, 91-115. 
Shaoul, J., Strafford, A., \& Stapleton, P. (2012). Accountability and corporate governance of public private partnerships. Critical Perspectives on Accounting, 23, 213-229.

Shenton, A.K. (2004). Strategies for ensuring trustworthiness in qualitative research projects. Education for Information, 22, 63-75.

Sherer, M., \& Turley, S. (Eds.). (1997). Current issues in auditing (3rd ed.). London: Paul Chapman.

Sikka, P., Puxty, A., Willmott, H., \& Cooper, C. (1998). The impossibility of eliminating the expectation gap: some theory and evidence. Critical Perspectives on Accounting, 9(3), 299-330.

Simnett, R., Carson, E., \& Vanstraelen, A. (2016). International archival auditing and assurance research: Trends, methodological issues, and opportunities. Auditing: A Journal of Practice \&Theory, 35(3): 1-32.

Simon, D.T., \& Francis, J.R. (1988). The Effects of Auditor Changing on Audit Fees: Tests of Price Cutting and Price Recovery. The Accounting Review, 63(2), 255-269.

Simunic, D.A. (1980). The pricing of audit services: Theory and evidence. Journal of Accounting Research, 18(1), 161-190.

Simunic, D.A. (1984). Auditing, Consulting, and Auditor Independence. Journal of Accounting Research, 22(2), 679-702.

Simunic, D.A., \& Stein, M. (1996). The impact of litigation risk on audit pricing: A review of the economics and the evidence. Auditing: A Journal of Practice and Theory, 15(2), 119-134.

Simunic, D.A. (2014). The market for audit services. Ch. 4. In Hay, D., Knechel, R.W., \& Willekens, M. (Eds.), Routledge Companion to Auditing (pp.33-42). Routledge: Abingdon and New York.

Singh, Y.K. (2006). Fundamental of Research Methodology and Statistics. New Delhi: New Age International Publishers.

Sing, H., \& Newby, R. (2010). Internal audit and audit fees: further evidence. Managerial Auditing Journal, 25(4), 309-327. 
Singh, H., Woodliff, D., Sultana, N., \& Newby, R. (2014). Additional evidence on the relationship between an internal audit function and external audit fees in Australia. International Journal of Auditing, 18, 27-39.

Spence, M. (1973). Job market signaling. Quarterly Journal of Economics, 87, 355-374.

Spence, M. (2002). Signaling in retrospect and the informational structure of markets. American Economic Review, 92, 434-459.

Spira, L.F., \& Page, M. (2010). Regulation by disclosure: the case of internal control, Journal of Management and Governance, 14, 409-433.

Starks, H., \& Trinidad, S.B. (2007). Choose your method: A comparison of phenomenology, discourse analysis, and grounded theory. Qualitative Health Research, 17(10), 1372-1380.

Steenkamp, N., \& Northcott, D. (2007). Content analysis in accounting research: The practical challenges. Australian Accounting Review, 17, 12-25.

Stein, M.T., Simunic, D.A., \& O'Keefe, T.B. (1994). Industry differences in the production of audit services. Auditing: A Journal of Practice and Theory, 13(Suppl), 128-142.

Stice, J. (1991). Using financial and market information to identify Pre-engagement factor associated with lawsuits against auditors. The Accounting Review, 66(3), 516-533.

Stiglitz, J. (2002). Information and the change in the paradigm in economics. American Economic Review, 92(3), 460-501.

Strauss, A.L., \& Corbin, J.M. (1998). Basics of qualitative research: Techniques and procedures for developing grounded theory. Thousand Oaks: Sage Publications.

Sturges, J.E., \& Hanrahan, K.J. (2004). Comparing Telephone and Face-to-Face Qualitative Interviewing: A Research Note. Qualitative Research, 4(1), 107-118.

Sudarsanam, S., \& Lai, J. (2001). Corporate financial distress and turnaround strategies: An empirical analysis. British Journal of Management, 12, 183-199. 
Sundgren, S., \& Svanström, T. (2013). Audit office size, audit quality and audit pricing: evidence from small- and medium-sized enterprises. Accounting and Business Research, 43(1), 31-55.

Sundgren, S., \& Svanström, T. (2014). Auditor-in-Charge Characteristics and Going Concern Reporting. Contemporary Accounting Research, 31(2), 531-550.

Thijssens, T., Bollen, L., \& Hassink, H. (2015). Secondary stakeholder influence on CSR disclosure: An application of stakeholder salience theory. Journal of Business Ethics, $132,873-891$.

Thinggaard, F., \& Kiertzner, L. (2008). Determinants of audit fees: Evidence from a small capital market with a joint audit requirement. International Journal of Auditing, 12(2), 141-158.

Thomas, D.R. (2006). A general inductive approach for analyzing qualitative evaluation data. American Journal of Evaluation, 27(2), 237-246.

Thomasson, A. (2009). Exploring the ambiguity of hybrid organisations: A stakeholder approach. Financial Accountability \& Management, 25(3), 353-366.

Thomasson, A. (2017). What about the boards? Issues of transparency and accountability in board composition. Ch. 10. In Lapsley, I., \& Knutsson, H. (Eds.), Modernizing the Public Sector: Scandinavian Perspectives (pp.149-162). Routledge: Abingdon and New York.

Toms, J.S. (2002). Firm resources, quality signals and the determinants of corporate environmental reputation: Some UK evidence. British Accounting Review, 34, 257-282.

Trahms, C.A., Ndofor, H.A., \& Sirmon, D.G. (2013). Organizational decline and turnaround: A review and agenda for future research. Journal of Management, 39, 1277-1307.

Trotman, A.J., \& Trotman, K.T. (2015). Internal audit's role in GHG emissions and energy reporting: Evidence from audit committees, senior accountants, and internal auditors, Auditing: A Journal of Practice \& Theory, 34(1), 199-230. 
United States Senate. (1977). Subcommittee on Reports, Accounting and Management of the Commission on Government Operations. The Accounting Establishment: A Staff Study. Washington DC. Government Printing Office.

United States Treasury. (2008). Advisory committee on the auditing profession: Final report, October 6, 2008. https://www.treasury.gov/about/organizationalstructure/offices/ Documents/final-report.pdf. (Accessed: May 28, 2019).

Vanstraelen, A., \& Schelleman, C. (2017). Auditing private companies: what do we know? Accounting and Business Research, 47(5), 565-584.

Van Maanen, J. (1979). Reclaiming qualitative methods for organizational research: A preface. Administrative Science Quarterly, 24(4), 520-526.

Verbeek, M. (2012). A guide to modern econometrics (4th ed.). Cornwall, UK: John Wiley \& Sons.

Viezer, T.W. (2000). Evaluating "within real estate" diversification strategies. Journal of Real Estate Portfolio Management, 6(1), 75-95.

Vourvachis, P., \& Woodward, T. (2015). Content analysis in social and environmental reporting research: trends and challenges. Journal of Applied Accounting Research, 16(2), 166-195.

Wallace, W. (1980). The economic role of the audit in free and regulated markets. Touche Ross Foundation.

Wallace, W. (1984). Internal auditors can cut outside CPA costs. Harvard Business Review, 62(16), 20.

Wallace, W. (2004). The economic role of the audit in free and regulated markets: a look back and a look forward. Research in Accounting Regulation, 17, 267-298.

Watts, R., \& Zimmerman, J. (1986). Agency problems, auditing, and the theory of the firm: some evidence. Journal of Law \& Economics, 26(3), 613-633.

Weber, R. (1990). Basic Content Analysis, 2nd ed, Newbury Park, California, Sage Publications. 
Willekens, M., Dekeyser, S., \& Simac, I. (2019). EU statutory audit reform: Impact on costs, concentration and competition, Study for the committee on economic and monetary affairs, policy department for economic, scientific and quality of life policies, European parliament, Luxembourg, 2019.

Winter, G. (2000). A Comparative Discussion of the Notion of 'Validity' in Qualitative and Quantitative Research. The Qualitative Report, 4(3), 1-14.

Woodliff, D., Gerrard, I., \& Houghton, K. (1994). Audit fees: the effects of auditee, auditor and industry differences. Managerial Auditing Journal, 9(7), 3-11.

Wooldridge, J.M. (2002). Econometric analysis of cross section and panel data. Cambridge, Mass: MIT Press.

Wouters, M., \& Wilderom, C. (2008). Developing performance measurement systems as enabling formalization: A longitudinal field study of a logistics department. Accounting, organizations and society, 33(4-5), 488-516.

Yilmaz, K. (2013). Comparison of Quantitative and Qualitative Research Traditions: epistemological, theoretical, and methodological differences. European Journal of Education, 48(2), 2013.

Zain, M., Zaman, M., \& Zulkifflee, M. (2015). The effect of internal audit function quality and internal audit contribution to external audit on audit fees. Internal Journal of Auditing, 19, 134-147.

Zerni, M. (2012). Audit Partner Specialization and Audit Fees: Some Evidence from Sweden. Contemporary Accounting Research. 29(1), 213-340.

Zerni, M., Haapamäki, E., Järvinen, T., \& Niemi, L. (2012). Do joint audits improve audit quality? Evidence from voluntary joint audits. European Accounting Review, 21(4), 731-765. 


\section{Appendices}

Appendix 1. Operationalization of control variables used in the different regression models

\section{Attributes \\ Client attributes}

Size

Complexity

Risk

Ownership

Industry

\section{Audit firm attributes}

Audit firm quality

Audit tenure

\section{Engagement attributes}

Audit report lag

Audit problems

Non-audit services

\section{Individual attributes}

Gender

Two auditors

\section{Variables}

Total assets

Number of subsidiaries

Total number of business segments

Percentage of foreign sales to total sales

Foreign employees as a percentage of total employees

Inventory and receivables divided by total assets

Systematic risk

Debt to equity ratio

Loss (negative net income)

Financial guarantee

Cash flow divided by total assets

Ownership structure

Industry dummy variables based on sector classifications used by Nasdaq Stockholm.

Audit firm dummy variables (Deloitte, EY, KPMG, PwC or non-Big 4 audit firm)

$\mathrm{PwC}$

Auditor specialist (industry level)

Audit firm change

Audit report lag

Audit opinion

Non-audit services

Gender of audit partners

Number of signing auditors 


\section{Papers}

The papers associated with this thesis have been removed for copyright reasons. For more details about these see:

http://urn.kb.se/resolve?urn=urn:nbn:se:liu:diva-163345 


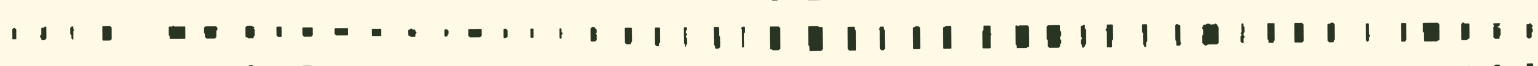

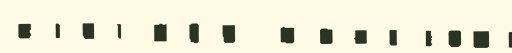

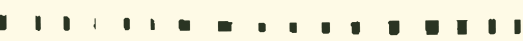

1. 1 1.

- - . - -

- -. - . .

1 1

1. . . . . . . .

- . - - . - . 1

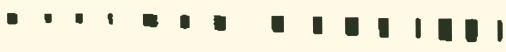

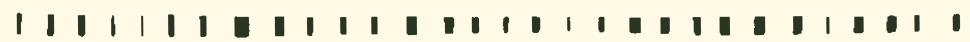

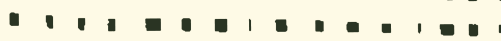

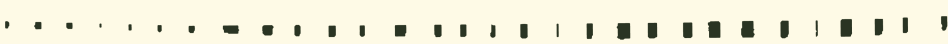

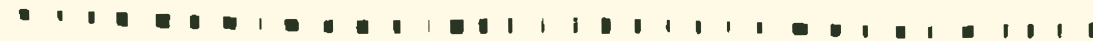

1.

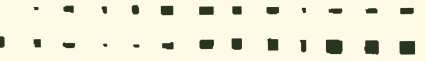

$1,0,100,100$

1. 1 10.010 0

\section{-.}

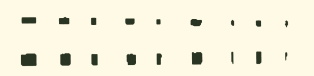

- I

1. . . . .

- \1 1

-

- 1. 1. . . .

- - - .

- ! - ! 1

. . . . . . - . -

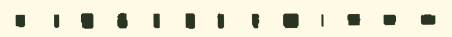

- 1. 1 1 1 10

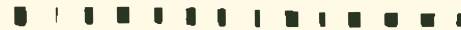

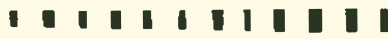

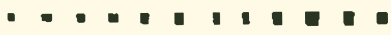
-

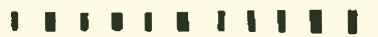

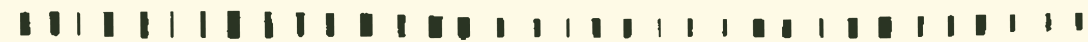

1.

\section{FACULTY OF ARTS AND SCIENCES}

Linköping Studies in Arts and Sciences, No. 779, 2020

Department of Management and Engineering (IEI)

Linköping University

SE-581 83 Linköping, Sweden

www.liu.se 